\author{
Journal of Analytic Divinity \\ International Refereed Journal \\ E-ISSN: 2602-3792 \\ Aralı/December, 2020/ 4 (2): ss-pp 166-195
}

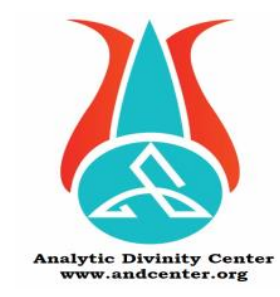

\title{
Müslümanların Seyahat Motivasyonları: Pozitif Psikoloji Perspektifinden Bir Değerlendirme
}

Muslims' Travel Motivations: An Assessment From a Positive Psychology Perspective

\section{Çiğdem Gülmez}

Dr. Öğr. Üyesi, Kastamonu Üniversitesi, İlahiyat Fakültesi, Felsefe ve Din Bilimleri Bölümü

Assist. Prof. Dr. Kastamonu University, Faculty of Theology, Department of Philosophy and Religious Sciences

Kastamonu/ Turkey, gulmez@kastamonu.edu.tr

orcid.org/0000-000168658464

\section{Makale Bilgisi | Article Information}

Makale Türü / Article Type: Araştırma Makalesi / Research Article

Geliş Tarihi / Date Received: 18 Eylül/September 2020

Kabul Tarihi / Date Accepted: 20 Temmuz/July 2020

Yayın Tarihi / Date Published: 15 Aralık/December 2020

Yayın Sezonu / Pub Date Season: Kış-Aralık/Winter-December

DOI: http:/ / doi.org/10.46595/jad.771648

Cite as / Atıf: Gülmez, Çiğdem. "Müslümanların Seyahat Motivasyonları: Pozitif Psikoloji Perspektifinden Bir Değerlendirme", Journal of Analytic Divinity 4/ 2 (December 2020), 166195.

İntihal: Bu makale, iThenticate yazılımınca taranmıştır. İntihal tespit edilmemiştir. Plagiarism: This article has been scanned by iThenticate. No plagiarism detected. Web: http:/ / dergipark.gov.tr/jad | e-mail to: editorjand@gmail.com

Copyright ( Published by Özcan Güngör, Ankara Yıldırım Beyazıt Üniversitesi, İslami İlimler Fakültesi / Ankara Yıldırım Beyazıt University, Faculty of Islamic Studies, Ankara-Turkey. Bütün hakları saklıdır. / All right reserved. 


\section{Öz}

Turizm olgusu, farklı ekonomik sınıflara, kültürlere, inanç biçimlerine, yaşam tercihlerine sahip kitleleri ilgilendiren çok boyutlu bir faaliyettir. Bu nedenle, turizm interdisipliner bir araştırma konusudur ve psikoloji bilimi bakımından da oldukça önemlidir. Özellikle pozitif psikoloji insanların turizm deneyimleriyle yakından ilgilenmekte, insanların psikolojik iyi oluşları ve turizm deneyimleri arasındaki ilişkiye odaklanmaktadır. Pozitif psikolojinin turizm motivasyonlarına ilişkin ulaştığı sonuçlar Müslüman turistler açısından oldukça önemlidir. Bu çalışmanın temel amacı Müslüman turistlerin seyahat motivasyonlarını pozitif psikoloji perspektifinden değerlendirmektir. Çalışma daha önce yapılmış araştırmalar, geliştirilmiş teoriler çerçevesinde mantıksal çözümlemeler yapan kuramsal bir çalışmadır. Çalışmada öncelikle pozitif psikoloji ve turizm ilişkisi üzerinde durulmuş, ardından tarihsel olarak Müslümanların seyahatleri ve günümüz Müslümanlarının turizm motivasyonları hedonik ve eudaimonik (hazcı ve mutçu) motivasyonlar temelinde değerlendirilmiştir. Pozitif psikolojiye göre hedonik turizmin mutluluk üzerine etkisi kısa süreli, eudaimonik turizmin ise daha uzun sürelidir. Pozitif psikolojinin turizm sahasındaki araştırma çıktıları ve Kur'an'ın Müslümanları bilgilenmeye, tefekkür etmeye, öğüt almaya, ders çıkarmaya, insanlarla ilişki kurmaya, Allah'ın yarattı̆̆ı düzeni görüp takdir etmeye teşvik eden seyahatle ilgili ayetleri göz önüne alındığında Müslüman turistlerin seyahatlerinin altındaki itici gücün daha çok eudaimonik olması gerektiği söylenebilir.

Anahtar Kelimeler: Din psikolojisi, Pozitif Psikoloji, Turizm, Hedonik Motivasyon, Eudaimonik Motivasyon.

\section{Abstract}

The phenomenon of tourism is a multi-dimensional activity that concerns masses that have different economic classes, cultures, beliefs, and life preferences. For this reason, tourism is an interdisciplinary research subject and it is very important in terms of science of psychology. Especially positive psychology is closely related to people's tourism experiences and focusees on the relationship between people's psychological well-being and tourism experiences. Positive psychology's conclusions on tourism motivations are also very important for Muslim tourists. The main purpose of this study is to evaluate the travel motivations of Muslim tourists from a positive psychology perspective. The study is a theoretical study that makes logical analysis within them frame of previous researches and developed theories. In the study, first of all, positive psychology and tourism relationship was discussed. Then historically muslims' travels and muslims' travel motivastions was evaluated on the basis hedonic and eudaimonic motivations. According to the positive psychology hedonic motivations are the driving force of mass tourism. and such experiences bring shortterm happiness. Alternative tourism activities directed by Eudaimonic motivations bring more permanent happiness. When considered the results of positive psychology researchs and the verses of the Quran that encourage Muslims to inform, contemplate, learn lessons, engage with others, it can be said that the driving force under the travels of Muslim tourists should be more eudaimonic.

Keywords: Psychology of Religion, Positive Psycholgy, Muslim, Tourism, Hedonic Motivation, Eudaimonic Motivation.

Journal of Analytic Divinity, https://dergipark.org.tr/tr/pub/jad Volume $4 / 2$ 


\section{Giriş}

Turizm, modern insan yaşamının doğal bir parçası haline gelmiştir. Ancak dinamik doğasından dolayı turizm kavramını kullanmak kadar anlamak, ne olduğunu tanımlamak kolay değildir. Her ne kadar kavramın ortaya çıkışını, insanlar arasında yayılmaya başlamasını turizm araştırmacıları tespit edebilse de bugünkü karmaşık doğası içinde turizm fenomenini insanların ne zaman deneyimlemeye başladıklarını belirlemek zordur. $\mathrm{Bu}$ zorluğun en temel nedeni insanlık tarihiyle eş olan seyahat kavramının turizmin merkezinde yer almasıdır. Araştırmacılar günümüzün turizm spektrumunda yer alan turizm türleri, motivasyonları ve hedefleriyle geçmişteki seyahatleri kıyaslayarak turizme tarihsel bir zemin oluşturmaya çalışmaktadır. Yer yüzünde insanın seyahat ettiği ilk günden beri turizmin var olduğu ileri sürülse de, tarihte hangi seyahatlerin turizm olarak değerlendirileceğine "seyahat amacı" göz önüne alınarak karar verilmektedir (Kozak vd., 2008).

Tarih boyunca insanlar seyahat etmek için çok farklı motivasyonlara sahip olmuşlardır. Yüzeysel bir değerlendirmeyle tarihin erken devirlerinde insanlık için seyahat nedenlerinin çok karmaşık olmadığı rahatlıkla söylenebilir. Bu erken devirlerde insanların temel seyahat motivasyonu hayatta kalmaktır. İnsanlar mevsimler değiştikçe, besin kaynakları tükendikçe yenilebilir bitkilerin ve av hayvanlarının bol olduğu bölgeleri bulmak için göç etmişlerdir. Yerleşik hayata geçilip temel ihtiyaçların belirli düzeyde temin edilmesiyle ve insan yaşamının daha karmaşık hale gelmesiyle seyahat motivasyonları da çeşitlenmiştir. Çin, Hint, Mezopotamya, Mısır, İran, Anadolu, Ege medeniyetleri seyahat tarihinde büyük dönüşümler yaşatmıştır. Bu medeniyetlerde askeri, dinî, ticari, sağlık, eğitim amaçlı seyahatler gerçekleştirilmiştir. Bazı araştırmacılar Babil'de paranın icadı ve M.Ö. 4000'de ticaretin gelişmesiyle, seyahatin ve turizmin de doğduğunu iddia etmektedir (Yeoman, 2008, 11). Daha sonra M.Ö. 2700'lerde inşa edilmeye başlayan Mısır piramitleri seyahatler için çekici bir merkez olmuştur. Bu mezarlar çok sayıda ziyaretçiyi cezbetmiştir. Ayrıca antik Mısır'da tarımın verimli olması ve firavunları onurlandırmak için yapılan festivallerde yılda birkaç kere insanlar bir araya gelmiştir. Benzer seyahatler Antik Yunan, Roma İmparatorluğu'nda da görülmüştür. Eski Yunanistan'da M.Ö. 776' da şehir devletlerinde Tanrı Zeus'u onurlandırmak için düzenlenen atletik yarışmalar daha sonra Olimpiyat Oyunları'na dönüşmüştür (Yeoman, 2008, 12). Romalılar döneminde ise hâkim olunan coğrafyanın da etkisiyle Mısır'da piramitlere, Olimpiyat oyunlarına, şifa için kaplıcalara rahatlıkla seyahatler gerçekleştirilmiştir. Romalılar yaptıkları yollar sayesinde bu seyahatleri kolay hale getirmiştir (Kozak vd., 2008, 27).

Turizm tarihiyle ilgili bu genel bilgilerden hareketle turizm için tanımı yeni tarihi eski bir fenomen denilebilir. Ancak modern dönemdeki turizm motivasyonları ile modern öncesi dönemde seyahat motivasyonlarının büyük farklılık gösterdiğine dikkat çekmek

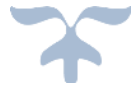


gerekir. Antik Mısır'da, Yunan'da ve diğer medeniyetlerde yaşama dair hemen hiçbir eylemin motivasyonel bakımdan salt bireysel haz için olmadığı söylenebilir. Zira o dönemlerde sanat, spor gibi akla gelebilecek hemen her şey tanrılar ve yöneticileri kutsamak için yapılmaktaydı. Buradan hareketle Antik Misır'da piramitleri ziyaret etmek, festivallere katılmak, Yunan'da olimpiyat oyunlarını izlemek için yola çıkan insanların temelde dinî nedenlerle seyahat ettiklerini ancak zevk ve eğlencenin de bir yan ürün olduğu söylenebilir.

Büyük kitleleri etkisi altına alan temelde zevk ve eğlenceyi amaç olarak sunan turizm modern zamanlara özgüdür ve boş zaman etkinliği olarak zevk amaçlı seyahatler Avrupa'da siyasi, sosyal, ekonomik, teknolojik dönüşümlerin yaşandığ1 18. yüzyılda görülmeye başlamıştır. Özellikle İngiltere bu dönemde keyfi seyahatler konusunda Avrupa'da öne çıkmaktadır (Kozak vd., 2008, 31). Turizm literatüründe, İngiliz iş adamı Thomas Cook'un kendi adıyla kurduğu taşımacılık şirketinin 1841 yılında İngiltere Leicester' den Loughborough'a 570 kişilik bir grupla yaptığı seyahat modern turizm çağının başlangıcı kabul edilmektedir (Yeoman, 2008 ,16; Çall1, 2015, 14; Kozak vd. 2008, 31).

Modern turizmin başladığı günden bugüne yaklaşık iki asır geçmesine rağmen turizmin üzerinde uzlaşılmış bir tanımı bulunmamaktadır. Turizmin dinamik doğası da bu türden bir tanımın yapılmasına imkân vermektedir. Dünya Turizm Örgütü'nün tanımına göre turizm;

İnsanların kişisel veya iş/mesleki amaçlarla devamlı olarak yaşanılan yerin dişındaki yerlere veya ülkelere hareket etmesini gerektiren sosyal, kültürel ve ekonomik bir olgudur. $\mathrm{Bu}$ insanlar ziyaretçi (turist, gezgin, yerli veya yabancı olabilir) olarak adlandırılır ve turizm onların turizm harcamaların da kapsayan aktiviteleriyle ilgilidir (UNWTO, https:/ / www.unwto.org/glossary-tourism-terms).

Turizm kavramı bu kadar geniş anlam çerçevesine sahip olunca hem tarihte hem de günümüzde yapılan bir çok seyahat turizm olarak adlandırılabilmektedir. Bilimsel bir toplantıya katılmak için seyahat eden de, inancının gereği hac vazifesini gerçekleştirmek için yola çıkan da, boş vakit, rahatlık, lüks için tatil yapan da bu tanıma göre turisttir. Buna göre insanlar isteyerek ya da istemeyerek, farkında olarak ya da olmayarak bir şekilde turizm hareketine katılmakta, turizm kapsamina girecek faaliyetleri yapmakta ve bu alandaki hizmetlerden yararlanmaktadır. Doğal olarak Müslümanların da tarihte ve günümüzde gerçekleştirdikleri seyahatler turizm başlı̆̆ının altında değerlendirilmektedir.

Günümüzde Müslüman turistlerin sayısı küresel turizm pazarında gittikçe artmaktadır. Müslüman turistler, küresel turizm pazarı tarafından keşfedilmesi gereken önemli bir niş pazar olarak görülmektedir. Bu nedenle Müslüman turistler çeşitli tartışmalara ve bilimsel araştırmalara konu edilmektedir. Müslümanların turizm pazarındaki önemi kadar Müslümanların neden seyahat ettiği de önemlidir. Turizm alanında "İnsanlar neden seyahat ediyor?" sorusu temelde turizm motivasyonların

Journal of Analytic Divinity, https://dergipark.org.tr/tr/pub/jad Volume $4 / 2$ 
anlamak için sorulmaktadır. Müslüman turistlerin seyahat motivasyonlarını anlamak için "Müslümanlar neden seyahat ediyor?" sorusu cevaplanmayı beklemektedir.

Pozitif psikoloji alanındaki araştırmalar ve geliştirilen teoriler, Müslümanların seyahat motivasyonlarını anlamak için iyi bir kavramsal çerçeve sunmaktadır. Bu çalışmada tarihsel ve güncel olarak Müslümanların seyahat motivasyonları ele alınmış, pozitif psikoloji alanındaki turizm motivasyonlarına ilişkin teorik yaklaşımlar ve ampirik sonuçlardan yararlanarak turizm ve mutluluk ilişkisi değerlendirilmiştir. Çalışma, daha önceki araştırmalar ve geliştirilen teoriler çerçevesinde mantıksal analizler yapan teorik bir çalışmadır.

\section{Pozitif Psikoloji ve Turizm}

Motivasyon insanların belirli zamanlarda belirli şekilde davranmalarını sağlayan çeşitli psikolojik ve fizyolojik faktörlerdir. Motivasyon kavramı psikoloji biliminin temel kavramları arasında olsa da insanla ilgili tüm bilim dallarının ilgi odağında olan bir kavramdır. Turizm özelinde ise "İnsan neden seyahat eder?" sorusu çeşitli sosyal bilim araştırmacılarının cevaplamaya çalıştığı temel soru olmuştur. Turizm motivasyonları, tutumları, faaliyet türü seçimleri, kişisel gelişim gibi araştırma konuları psikolojinin genç alt disiplinlerinden biri olan pozitif psikolojinin de yakından ilgilendiği konulardır (Pierce - Parker, 2013). Pozitif psikoloji turizm sahasında en temelde turizm ve mutluluk ilişkisini ele almaktadır. Pozitif psikoloji bireyin olumlu özelliklerine odaklanan, yaşamı neyin mutlu, değerli ve anlamlı kıldığını bilimsel olarak tespit etmeye çalışan araştırma alanıdır. Pozitif psikoloji alanında mutluluğa temel iki yaklaşım vardır. Bunlardan birincisi hedonik mutluluk ikincisi eudaimonik mutluluktur. Hedonik mutluluk daha çok hazza ve olumlu duyguları yaşamaya dayalıdır. Felsefi kökleri M.Ö. 4. yüzyılda yaşamış olan Antik Yunan düşünürü Aristippos'a dayanmaktadır. Ona göre hayatın amacı acıdan kaçınmak ve mümkün olduğu kadar çok haz duygusunu yaşamaktır. Haz koşulsuz iyidir, diğer şeyler hazza araç oldukları takdirde istenmeye değerdir (Akarsu, 1998, 62). Hedonik mutluluk pozitif psikoloji alanında öznel iyi oluş (subjective well-being) olarak tanımlanmaktadır (Rayn - Deci, 2001). Eudaimonik mutluluk ise erdemlere, anlamlı ve amaçlı bir yaşam sürmeye dayalı olan mutluluktur. Eudaimonik mutluluk anlayışının felsefi kökleri ise Aristoteles'e dayanmaktadır. Eudaimonia ilksel anlamda bir daimon'u olmadır. Daimon Eski Yunanca'da yaşamı kuşatan, insan yazgısını belirleyen güç anlamına gelmektedir. Aristoteles'e göre eudaimonia insanın yaşamındaki en iyi, en soylu, en istenilen şeydir. Mutluluk insanın en yüksek ve en son amacıdır (Güçlü vd. 2002, 521). Bu amaca ise erdemlere uygun eylemlerle ulaşılır. Erdem ve bilgelikle insan kendine hâkim olur ve kendini gerçekleştirir. Aristoteles'e (2014) göre hazza adanmış bir yaşam insana layık bir yaşam değildir. Haz eylemlerin amacı değil, erdemlere uygun bir yaşamın neticesinde ortaya çıkan sonuçtur. Pozitif psikolojide bu felsefi geleneği temel alan eudaimonik 
yaklaşım kişisel gelişimin, kendini gerçekleştirmenin, kendini geliştirmenin ve anlamlı bir yaşam sürmenin mutluğa ulaştıracağını kabul etmekte ve eudaomonik mutluluğu psikolojik iyi oluş olarak tanılamaktadır (Rayf, 1989, 2014).

Son yillarda pozitif psikoloji alanında turizm deneyimlerinin mutluluk düzeylerine etkisi araştırma konusu edilmektedir (Filep - Pearce, 2014, 2016; Filep - Laing, 2018; Nawjin, 2011a, 2011b; Nawijn - Mitas, 2012; Pearce, 2009; Pearce vd., 2010; Voigt vd., 2010; Vogit, 2017). Çok çeşitlilik gösteren turizm motivasyonları pozif psikoloji perspektifinden hedonik ve eudaimonik mutluluk olmak üzere iki kategoriden birine indirgenmekte ya da bütünleştirilmektedir. Esasında turizm mutluluk ilişkisini ele alan çalışmalar daha çok hedonik/öznel mutluluğa odaklanmakla birlikte yakın dönemlerde eudaimonik mutluluk/psikolojik iyi oluşu veya her ikisini birleştiren bütüncül, sentez çalışmalar yapılmaktadir.

Turizm denildiğinde daha çok hedonik veya öznel iyi oluşu artıran turizm akla gelmektedir. Çünkü turizm alanı hedonik bir tüketim alanı olarak kabul edilmektedir. Turistlerin hedonist olduklarına ilişkin sterotipik imaj deniz, kum, güneş üçlüsünden ve bazen de dizginlemenemez tüketim arzusundan gelmektedir. Turistler genellikle keyifli aktiviteler ararken, onların turizm seçimlerini de turizm endüstrisi hedonik hedeflere başarılı biçimde yönlendirmektedir (Gnoth, 1997). Deniz-kum-güneş tatili olarak isimlendirilen dinlenme, eğlenme amaçlı turizm günümüzde hala en önemli seyahat nedeni olarak görülmektedir. Bu turizm türününün daha çok tercih edilmesinde insanların yaşam koşullarının rolü büyüktür. Yılın büyük bir kısmını çalışarak geçiren insanlar izin dönmelerinde yorgunluklarını atmak, günlük yaşamın stresinden ve rutininden uzaklaşmak için tatil yerlerini tercih etmektedir. Bir diğer ifadeyle insanlar bu tatillerle kendilerine olumsuz duygular yaşatan ortamlardan uzaklaşarak olumlu duyguları daha çok deneyimlemeyi yani öznel iyi oluş düzeylerini artırmayı hedeflemektedir. Yapılan araştırmalar da turistlerin bu beklentilerini tatilin bir derece karşıladığını göstermektedir. Hedonik mutluluğa odaklanan çalışmalar tatil ile yaşam doyumu ve öznel iyi oluş arasında poztif ilişki olduğunu, turizmin bireylerin mutluluk düzeyini artırdığını desteklemektedir (Sirgy, 2009; Sirgy, 2012; De Bloom et al., 2010; Nawijn, 2010; Nawijn, 2011a). İnsanlar tatil sırasında kendilerini daha sağlıklı ve enerjik hissetmekte, daha poztif duygular yaşamakta ve yaşamdan daha fazla doyum sağlamaktadır. Pearce (2007) turizmi insanların gezegende mutluluk düzeyini artırmak için kendi elleriyle geliştirdiği en büyük ticari sistem olarak görmektedir.

Nawijn ve Veenhoven (2011) Almanya' da 1990'ların başından 2003'e kadar eğitim, sağlık, iş, mutluluk gibi 18 farklı alanda kişisel bilgilerin kayıt altına alındığı bir veri tabanını kullanarak yaklaşık 20 bin kişi üzerinden mutluluk ile boş zaman aktiviteleri arasındaki ilişkiyi belirlemeye çalışmıştır. Bu çalışmada diğer boş zaman faaliyetlerine kıyasla tatil seyahatinin mutluluk üzerine en fazla etkiye sahip olduğu gözlenmiştir. Etkisi kısa olmakla birlikte tatil seyahatleri mutluluktaki varyansın yaklaşık \%2' sini açıklamıştır.

Journal of Analytic Divinity, https://dergipark.org.tr/tr/pub/jad Volume 4/2 
Mutluluğu öznel iyi oluş olarak tanımlayan Nawjin (2010) tatillerin gerçekten ne kadar mutlu ettiğini araştırmıştır. Hollanda'da 481 uluslararası turistin katıldığı çalışmada katılımcıların günlük ruh hali ve genel yaşam memnuniyetlerini ölçmüştür. 19 gün boyunca farklı günlerlerde, farklı lokasyonlarda ve farklı faaliyetler içindeyken turistlerin duygu durumlarını belirlemiştir. Tatil boyunca turistlerin duygu durumu dalgalı bir gidişat izlemekle birlikte 10 üzerinden ortalama 8,2 olarak ölçülmüştür. Benzer şekilde turistlerin yaşam doyumları 10 üzerinden otalama 8,4 olarak puanlanmıştır. Ayrıca Nawjin turistlerin duygu durumlarının ve yaşam doyumlarının sosyodemografik değişkenlere, tatil türüne (kültürel tatil, doğa tatili, şehir gezisi, plaj tatili, gemi tatili, etkinlik tatili) yapılan aktivitelere (şehir turu yapma, müze ziyareti, , alışveriş, tarihi yerleri görme, dinlenme) göre değişim göstermediğini ifade etmiştir. Ancak duygu durumlarının tatilin başında düşük, ikinci evrede yüksek, üçüncü evrede düşük ve son evresinde yeniden yükseliş gösterdiğini gözlemlemiştir. Nawjin vd. (2013), yine benzer bir çalışmada 39 Amerikalı ve Hollandalı turistin duygu durumlarını tatilleri sürecinde günlük olarak takip etmiştir. Bulgular, turistlerin duygu durumlarındaki dalgalanmaların tatilin uzunluğu ile ilişkili olduğunu göstermiştir. Nawjin vd. 8 ilâ 13 gün arasında bir geziye çıkan turistlerin, yolculukları sırasında duygularının dengesinde önemli değişiklikler yaşadıklarını ve turistlerin genel olarak kendilerini iyi hissederken, tatilin sonunda bu pozitif duyguların azalmaya başladığını tespit etmiştir. Ancak Nawjin (2012) her tür tatilin öznel mutluluğu artırdığını ileri sürmektedir. de Bloom vd. de (2017) evdeki boş zaman aktivitelerine kıyasla seyahat sırasında insanların öznel iyi oluşunun daha yüksek, ruminatif düşüncenin daha az olduğunu ölçümlemiştir.

Garcês vd. (2018) sosyal bilimler alanındaki çeşitli veri tabanlarında pozitif psikoloji, iyi oluş, mutluluk, turizm, ziyaretçi, seyahat kavramlarını taratarak 2007 ve 2017 yılları arasında pozitif psikoloji ve turizmi birlike ele alan literarürü taramış ve ulaştıkları 49 makaleye meta-analiz uygulamışlardır. Meta-analiz sonrasında, turizm sahasında iyi oluşun anahtar bir kavram olduğunu, turizmin hem yerliler, hem de turistlerin iyi oluş düzeylerini pozitif yönde etkilediğini dile getirmişlerdir.

Tatil turizminin insanların subjektif iyi oluşlarını pozitif yönde etkilediğine dair sonuçlar bulunsa da arştırmacılar bu etkinin zayıf olduğunu (Milman, 1998) veya tatil süresinin etkili olduğunu da ifade etmektedir (Nawjin, 2010, 2011a, 2013). Gilbert ve Abdullah (2004) ön test ve son test tasarımlı bir araştırmada tatilin turistlerin yaşam doyumunu artırdığını ancak etki büyüklüğünün çok küçük olduğunu dile getirmektedir. Onlar pozitif duygu durumunun tatil boyunca benzer düzeyde seyretmemekle birlikte tatilin genel olarak olumlu duyguları artırdığını ve yaşam doyumu sağladığını ifade etmektedir. Nawjin ve arkadaşları (2010) 1550 Hollandalı bireyin katılımıyla gerçekeştirdikleri ön test ve son test tasarımlı bir başka çalışmada tatile çıkanları 
çıkmayanlarla kıyaslayarak tatilin mutluluk üzerindeki etkisini incelemiştir. 974 turistten tatilleri çok rahat geçenlerin mutluluk düzeyleri eve döndükten sonra biraz yüksek seyretmiştir. Genel karşılaştırmada ise gezi sonrasında turistlerin mutluluk düzeyi ile turist olmayanların mutluluk düzeyleri arasında fark olmadığını gözlemişlerdir. de Bloom, Geurts ve Kompier (2010) de benzer şekilde çalışan bireylerin tatil deneyimlerinin sağlık ve iyi oluş düzeylerine tatil sürecinde etkide bulunduğunu, ancak bu pozitif tatil etkisinin işe dönüldüğünde hızlı biçimde düşüştüğünü göstermiştir. Tatilin uzun ya da kısa olmasına göre bu sonuç farklılaşmamıştır.

Sosyal turizm ${ }^{1}$ bağlamında turizmin yaşam kalitesi ve öznel iyi oluşla ilişkisini ele alan bir araştırmada tatil öncesi iyi oluş ve tatil sonrası iyi oluş karşılaştırmalı olarak incelenmiştir. Çalışmada, sosyal turistler arasında tatilin öznel iyi oluş düzeyine pozitif katkı sağladığına ve turizmin yaşam kalitesine pozitif etkide bulunduğuna dikkat çekilmiştir (McCabe - Johnson, 2013). Sosyal turistlerde tatil, özellikle mutluluk, iyimserlik, aile hayatı, aile ilişkileri üzerinde yüksek pozitf etki yaratmıştır. Ancak yaşam koşulları oldukça zor olan sosyal turistlerin duygu durumlarındaki ve iyimserliklerindeki bu pozitif iyileşme kısa ömürlü olmuştur. Araştırmacılar tatilin uzun süreli iyilikten ziyade kısa vadeli etkiye sahip olduğunu dile getirmektedir. Ancak turistlerin yaşam kaliteleri üzerine tatilin önemli bir etkisi olduğunu, özellikle aile bağlarında iyileşme ve aileyle geçirilen zamanın kalitesinde bir artış olduğunu bildirmişlerdir.

Görüldüğü üzere hedonik motivasyonun ürünü olan tatiller pozitif duygularda kısa ömürlü, geçici bir yükselme sağlamaktadır. Dinleme ve eğlenme amaçlı tatil turizmi her ne kadar hala çok canlı bir turizm türü olsa da mutluluk üzerine bu geçici etkisinden dolayı insanların salt hedonik olmayan motivasyonlarla farklı turizm türlerine yöneldikleri gözlenmektedir. İşte bu turistler eudaimonik bir motivasyonla hareket etmektedir (Filep Pearce, 2014). Araştırmacılar yeni bilgi edinme arzusunda olan ve yeni deneyimler arayan bir gezgin dalgasının büyüdüğüne işaret etmektedir. Garcês vd. (2018) günümüzde bireysel gelişim ve kendini gerçekleştirmeye odaklanan yeni bir "deneyim ekonomisi" fikrinin yükselişine şahitlik edildiğini belirtmektedir. Deneyim ekonimisi olarak yükselen bu trend içinde turistlerin de yeni bir tutuma sahip oldukları, turizm seyahatlerinde daha eudaimonik hedeflere yöneldiklerine dikkat çekilmektedir. Turizm endüstrisinin çoğunlukla salt tüketime dayalı olması, hepsi bir arada paket turların standartlı̆̆ı, turizm endüstrisinin ürün çeşitlerini artıramaması, birkaç kere bu tür tatili deneyimleyen insanların hedonik adaptasyon yaşamaları, fiziksel olarak dinlenseler bile zihinsel, psikolojik olarak yenilenmiş hissedememeleri gibi nedenlerle insanlar farklı turizm alanlarına yönelmektedir. Eudaimonik bir motivasyona sahip olan turistler, iyi ve anlamlı eylemlerde bulunmayı, kendini geliştirmeyi ve gerçekleştirmeyi hedeflemektedir. Bu

\footnotetext{
1 Sosyal turizm “düşük gelirli" kesimlerinin turizme iştirak etmesinden doğan tüm kavram ve olaylar olarak tanımlanmaktadır. (Bkz. Avrupa' da Sosyal Turizm Barcelona Bildirgesi,

http://www.festtravel.com/avrupada-sosyal-turizm-barcelona-bildirgesi )
}

Journal of Analytic Divinity, https://dergipark.org.tr/tr/pub/jad Volume $4 / 2$ 
turizm türlerini tercih eden insanlar deniz-kum-güneş turizminde olduğu gibi pasif değil aktiftir. Harrrison (2003) turizm seyahatinin hayatın anlamına katkısı üzerine çok çeşitli kaynakları kullanarak (fotograf, video, dergi, öznel raporlar, vb) yaptığı çalışmada seyahatleri anlamlı kılan şeyleri dört başıkta toplamıştır. Birincisi insanlarla yakınlık ve ilişki kurmaya, ikincisi kişisel estetiği ifade etme/yansıtmaya, üçüncüsü kendi evini/yurdunu keşfetmeye, anlamaya ve dördüncüsü ise anlamlı bir dünya oluşturmaya yardımcı olmasıdır.

Sağlık turizmi ${ }^{2}$ ve iyi oluş ilişkisine odaklanılan bir çalışmada insanların turizm deneyimleri hedonik ve eudaminoik olarak iki başlık altında toplamış ve bu deneyimlerin mutluluk düzeylerine etkisini karşılaştırmıştır (Vogit, 2017). Avusturalya' da sağlık turizmi için bulunan 27 kişiyle derinliğine görüşme yapmıştır. 27 turistin 15'i spa turizmi, 6's yaşam stili turizmi ${ }^{3}$ ve $10^{\prime}$ u manevi inziva turizmi gerçekeleştirmiştir. Turistlerden $4^{\prime}$ ü ise üç farklı sağlık turizmi deneyimlerinden ikisine katılmıştır. Araştırmada katılımcıların verdikleri cevaplar hedonik ve eudaimonik temalara ayrılmıştır. Araştırma sonuçlarına göre en çok güzellik/spa deneyimi yaşayanların cevaplarından hedonik karakteristikte temalar üretilmiştir. Bu gurubun \%40'1 zevk, \%93'ü gevşeme, \%73'ü duyusal uyarılma deneyimleridiklerini belirtmiştir. Yaşam stili grubunda olanların \%33'ü zevk, \%17'si gevşeme kavramlarıyla deneyimlerini tanımlamış, deneyimlerini duyusal uyarılmayla tanımlayan hiç olmamıştır. Manevi inziva grubundakilerin ise \%10'u gevşemeyle deneyimlerini tanımlamıs, zevk ve duyusal uyarılmayla tanımlayan hiç kimse olmamıştır. Deneyimlerin etkileri hususunda ise güzellik/spa grubundakilerin \%73'ü deneyimlerinin pozitif etkisinin çok kısa sürdüğünü ifade etmiştir. Üç grubun verdikleri cevaplardan eudaimonik karakterde olanlar ise şöyle sıralanmıştır: Manevi inziva grubunun \%10'u deneyimlerini özel bir dünyaya ait olma hissiyle tanımlamıştır. Güzellik /spa grubundakiler ve yaşam stili grubundakilerden deneyimlerini bu kavramla tanımlayan kimse çımamıştır. Manevi inziva grubundakilerin \%50'si deneyimlerini kariyer gelişimiyle tanımlarken, diğer iki grupta bu tema tespit edilmemiştir. Yaşam stili grubundakilerin $\% 50$ 'si, manevi inziva grubundakilerin $\% 40$ '1 deneyimlerini çaba ve azim olarak tanımlamıştır. Ayrıca yaşam stili turizmini tercih eden bazı turistler ve manevi inziva grubundaki bazı turistler deneyimlerini 'sert', 'zorlu', 'biraz rahatsız edici', 'sinir bozucu' ve 'çok fazla çaba sarf edici" olarak tanımlamışlardır. Bununla birlikte, birçok

\footnotetext{
2 İngilizcede "wellness tourism" olarak ifade edilen kavram Türkçeye sağlık turizmi olarak aktarılmıştır. Sağlık turizmi; insanların fiziksel, psikolojik veya manevi faaliyetlerle sağlığı ve refahı teşvik etmek amacıyla seyahat etmesidir.

3 İngilizcede "lifestye tourism" olarak ifade edilen kavram "yaşam tarzı turizmi" olarak aktarılmıştır. Yaşam tarzı turizmi; bireylerin yaşam tarzlarından kaynaklanan istek ve arzuları karşılamaya çalışan niş bir turizm türüdür. Yaşam tarzının tüketicilerin karar alma sürecinde etkili olduğu gerçeğinden hareket ederek, yaşam tarzlarına uygun ürünleri tüketiciye sunmayı hedefler (Bkz. Michael J. Gross, Lifestyle tourism,

https://link.springer.com/content/pdf/10.1007\%2F978-3-319-01669-6_277-1.pdf)
} 
katılımcı engellerin üstesinden geldikten ve sebat ettikten sonra deneyimlerini derinden tatmin edici ve anlamlı olarak tanımlamıştır. Güzellik/spa grubunda ise bu tema görülmemiştir. Yaşam stili grubundakilerin \%67'si, manevi inziva grubundakilerin $\% 80$ 'inde bilgi, eğitim ve beceri teması görülmüsstür. Yaşam stili grubundakilerin $\% 67$ si, manevi inziva grubundakilerin \%70'i deneyimlerini tatmin olma ve kimlik oluşturma temalarıyla nitelemiştir. Ayrıca yaşam stili grubundakilerin \%67'si, manevi inziva grubundakilerin \%70'i deneyimlerin mutluluk düzeylerine uzun süreli etkide bulunduğunu belirtmiştir. Spa grubundakilerin hiçbiri deneyimlerini eudaimonik karkateristiklerle nitelememiştir. Vogit araştırmasında eudaimonik motivaysona sahip tursitlerin deneyimlerinin kimlik inşalarına katkı sunduğunu, çevrelerine, kendilerine ve tüm evrene karşı bakış açılarında olumlu değişimler yaşadıklarını, deneyim sırasında öğrendikleri şeylerin günlük yaşam biçimlerinde davranışsal değişiklikler sağladığını (düzenli olarak meditasyon yapma ya da daha sağliklı bir şekilde yemek yeme) hatta yaşam kararları için bir katalizör görevi gördüğünü ifade etmektedir. Örneğin manevi inziva grubundaki turistlerden birinin deneyimi sonrasında stresli işinden vazgeçtiğini ve bir süre evde kalmaya karar verdiğini belirtmiştir. Eudaimonik bir motivasyonla deneyimlenen turizmin bu kadar kalıcı, derin değişimler yaşatabilmesi pozitif duyguların yanısıra negatif ama sağlıklı (sabretme, zorlanma, tahammül etme gibi) duyguları yaşatmasıyla da ilişkili olabilir.

Turizm mutluluk ilişkisini hedonik, eudaimonik perpektifle birlikte bütüncül ele alan yaklaşımlarda bulunmaktadır. Özellikle pozitif psikoloji sahasındaki mutluluk kuramlarından da turizm araştırmalarında yararlanılmaktadır. Örneğin Filep turizm ve mutluluk ilişkisine pozitif psikolojinin kurucu ismi Seligman'nın otantik mutluluk kuramı temelinde yaklaşmaktadır. Martin Seligman'ın otantik mutluluk kuramı turist motivasyonlarını açıklamak için başvurulabilecek bütüncül alternatif bir bakış sunmaktadır. Filep de otantik mutluluk teorisinin turist mutluluğunu açıklamak için oldukça uygun bir çerçeve olduğunu belirtmektedir. Seligman iyi oluşu veya kendi isimlendirmesi ile otantik mutluluğu beş boyutta incelemiştir. Bunlar olumlu duygular (positive emotions), bağl1lık (engagement), olumlu ilişkiler (positive relationships), anlam (meaning) ve başarılar (accomplishments) dır (Seligman, 2011). Filep (2016) Seligman'nın kuramından yola çıkarak turistlerin deneyimlerin bütünüyle olamasa bile benzer kavramsal yapılarla anlaşılabileceğini ileri sürmüştür. Filip'e $(2009,2016)$ göre tursitler seyahatlerinde (ilgi, sevinç, memnuniyet gibi) pozitif dugyuları daha çok yaşamakta, akış veya öz farkındalık gibi bir faaliyete bağll1ık hissini tecrübe etmekte veya bazı seyahatlerde daha üstün bir amaca hizemet ettikleri düşüncesiyle faaliyetleri anlamlı hale gelmektedir. Aryıca turizmin stresi azaltarak, uyku kalitesini iyileştirdiği ve kardiyovasküler sağlı̆̆1 artırdığını ileri sürmektedir.

Pozitif psikolojinin bir diğer kurucu isimi Mihaly Csikszentmihalyi ile John Coffey (2017) bütüncül bir pozitif turizm teorisi geliştirmiştir. Onlar insanlar neden seyahat eder sorusuna geliştirdikleri oldukça kapsamlı motivasyon teorisiyle cevap vermeye

Journal of Analytic Divinity, https://dergipark.org.tr/tr/pub/jad Volume $4 / 2$ 
çalışmışlardır. Csikszentmihalyi ve Coffey; içsel, dışsal, hedonik ve eudaimonik motivasyonları dikkate alarak dört kutuplu bir seyahat motivasyon modeli ileri sürmüşlerdir. Bu modeli iki boyutlu bir koordinat sistemi üzerinde göstermişlerdir (Bkz. Şekil A). Koordinat sisteminin X ekseninin pozitif dış tarafı kuvvetli içsel motivasyonu, negatif dış tarafı kuvvetli dışsal motivasyonu göstermektedir. Koordinat sisteminin $Y$ ekseninin pozitif dış tarafı kuvvetli eudaimonik motivasyonu, negatif dış noktaları ise kuvvetli hedonik motivasyonu göstermektedir.

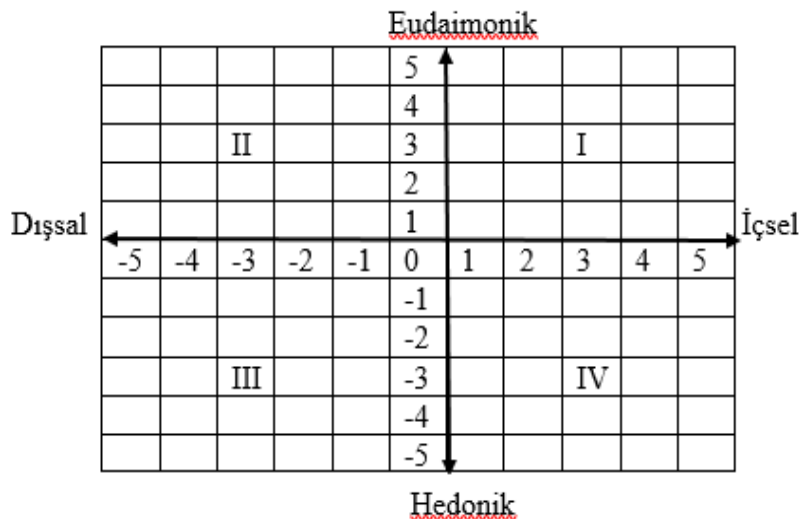

Şekil 1. Seyahat Motivasyon Matrisi (Csikszentmihalyi ile John Coffey, 2017: 125)

Csikszentmihalyi ve Coffey'e (2017: 125) göre büyük olasılıkla bir iş görüşmesi, çocukların isteği, dini bir emir gibi zorunlu gerekçelerle seyahate çıkan kişiler $\mathrm{x}$ ekseninin negatif dış ucunda, yeni coğrafyalar görmek, yeni kültürler keşfetmek, rahatlamak, tatil yapmak gibi içsel nedenlerle, kendi özgür iradeleriyle seyahat eden kişiler ise X eksenin pozitif dış ucundadır. Öte taraftan büyük olasılıkla y eksenin negatif dış ucundaki kişilerin hedefi iyi vakit geçirmek, yeni yerlerin, insanların, tatilin, yemeklerin tadını çıkarmakken, y ekseninin pozitif diş ucundaki kişilerin hedefi ise daha çok kendini geliştirmek, anlamlı aktivitelerde bulunmak, yeni yerlerin tarihi, kültürü, mutfak çeşitliliği, inançları, değerleri hakkında bilgi edinmektir.

Modele göre tipik bir turist modelin dört numaralı bölgesinde bulunacaktır. Tipik turist özünde hedonik hedeflere motivedir. Csikszentmihalyi ve Coffey $(2017,126)$ ideal bir seyahatin muhtemelen birinci bölgede yüksek puanlara denk geleceğini öngörmektedir. Yani bireyi entelektüel ve duygusal olarak besleyici fırsatlar sunan aynı zamanda gönüllü bir yolculuk. En az arzu edilecek seyahatin ise modelin üçüncü bölgede düşük puanlara denk gelen bir seyahat olacağını ileri sürmekteler. Bu seyahat, hem dişsal hem de hedonik motivasyonla gerçekleşen bir seyahattir. 
Csikszentmihalyi ve Coffe (2017) her ne kadar dört gruba ayırarak motivasyonları inceleseler de deneyim noktasında bunların birbirinden tamamen ayrışmış durumda olmadığını ifade etmektedirler. Yani dışsal motivasyonla çıkılan bir seyahat içsel bir motivasyona evrilebilirken, hedonik motivasyonla çıklan bir seyahatte eudaimonik bir seyahate dönüşebilir veya tam tersi eudaimonik bir motivasyonla seyahat eden biri hedonik ödüllere açık olabilir. Örneğin çocuklarının okul gezisine zorunlu olarak iştirak eden ebeveynler gördükleri yerlere hayran olabilirler, iyi ki gelmişiz diyebilirler. Böylece dışsal motivasyon içsel bir motivasyona dönüşebilir. Bir iş adamı içsel bir motivasyonla rahatlamak, dinlenmek için tatile çıkabilir. Kaldığı otelde iş dünyasından tanıştığı biriyle tatilinin geri kalan kısmını ortak iş planı yaparak geçirebilir. İçsel bir motivasyonla çıkılmış tatil, bir anda iş görüşmesine dönüşebilir. Benzer şekilde tamamen keyif, haz odaklı olarak tatile çıkmış biri bir süre sonra yerel mimari, yaşam biçimleri, inançlar, değerler konusunda bilgi edinmeye başlayabilir veya tamamen kendini geliştirme motivasyonuyla yola çıkan biri de bilgi edinirken haz ve keyif duyabilir. Motivasyonlar bu biçimde birbirine evrilme potansiyeline sahiptir ancak bu modelde motivasyonların hangisinin psikolojik ve fizyolojik iyilikle daha çok ilişkili olduğu konusunda net bir sınır çizmenin zor olduğuna işaret edilmektedir. Dört güdü farklı yoğunluklarda ve farklı kombinasyonlarda olabilir. Seyahate çıan birey başlangiçta bu bölgelerden herhangi birinde daha yüksek puanlanırken seyahat sürecinde modelin başka bölgelerinde konumlanabilir.

Csikszentmihalyi ve Coffey'in modeli oldukça bireyselleştirilmiş bir modeldir. Literatürde seyahatler; türlerine (deniz kum güneş, kış, spor vb), motivasyonlarına veya tatil aktivitelerine göre sinıflandırılırlar. Ancak Csikszentmihalyi ve Coffey'e (2017) göre iki kişi tamamen farklı güdülerle aynı aktivitede veya tamamen aynı güdülerle farklı aktivitelere yönelebilirler. Böylece psikolojik ve fizyolojik iyilik için tamamen farklı faydalar ve sonuçlar doğabilir. Örneğin bir kişi farklı bir coğrafyayı, kültürü ziyaret ederek yaşamını anlamlandırmaya motive olurken, bir başkası ailesini ziyaret ederek aynı anlamı bulabilir. Bu modele göre bu iki kişi farklı aktiviteler yapmalarına rağmen aynı motivasyona sahiplerdir. Ancak aynı türden aktiviteyi içsel olarak yapan kişinin elde edeceği mutluluk, dışsal olarak yapan kişinin mutluluğundan daha fazla olacaktır.

Pozitif psikoloji perspektifinden Csikszentmihalyi ve Coffey'in teorisi gibi insan doğasının dinamik ve karmaşık yapısını dikkate alan bir diğer yaklaşım Smith ve Diekmann'a aittir $(2017,9)$. Smith, Diekmann pozitif psikoloji sahasında turizmde iyi oluşu açıklayan yaklaşımları incelemiş ve bunları birleştirerek bütüncül turizm iyi oluş modeli geliştirmişlerdir. Smith, Diekmann insanın iyi oluşu üzerine etkileri bakımından turizm türlerini; kısa vadeli, orta vadeli, uzun vadeli ve kalıcı olmak üzere dört gruba ayırmışlardır. Kısa vadeli olan hedonik turizmdir. Deniz-kum-güneş tatili bu gruptadır. Orta vadeli olan hedonik ve eudaimonik turizmin birleşimidir. Örneğin gönüllü turizmi, kültür turizmi yaparken güneşlenmek, dinlenmek gibi. Uzun vadeli etkiye sahip olan eudaimonik, obejktif hedef listesi ve otantik iyi oluşun birleşimidir. Örneğin yardım gezileri yapmak, gönüllü turizmi, inziva turizmi, hac yolcuğu gibi seyahatler.

Journal of Analytic Divinity, https://dergipark.org.tr/tr/pub/jad Volume $4 / 2$ 
Araştırmacılara göre kalıcı mutluluk/iyi oluş etkisine sahip turizm ise utiliteryan turizmdir. Turizmde utilieryanizm tüm insanlık için yaşam kalitesini maksimize etme ve otantik mutluluk ile kazanılır. Kalıcı mutluluğu getirecek olan turizm uygulamalarına ekoturizm, etik ve yerli turizm örnek verilebilir. Smith, Diekmann turizmde bu farklı iyi oluş modellerini birleştirerek bütüncül turizm iyi oluş modelini aşağıdaki şekilde göstermişlerdir.

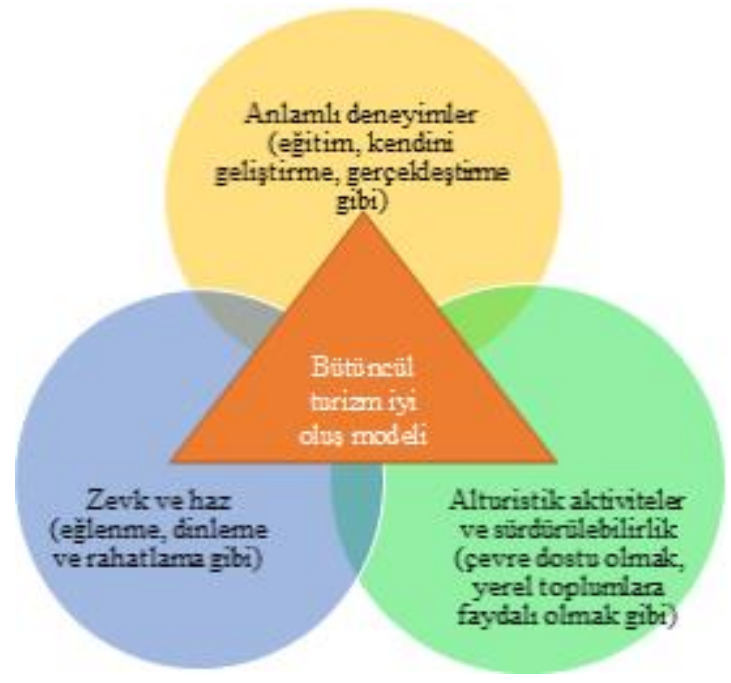

Şekil 2: Bütüncül Turizm İyi Oluş Modeli (Smith, Diekmann, 2017: 10).

Araştırmacılara göre optimum düzeyde ve kalıcı iyi oluş bu üç boyutun birleşimiyle kazanılabilir. Bu model turist motivasyonlarına oldukça geniş bir perspektiften bakmaktadır. Smith ve Diekmann (2017: 10), önceden oluşturulmuş, standart paket turlarla bu türden bir turizm deneyimin imkânsız olmasa da gerçekleşme olasılığının düşük olduğunu ifade etmektedir. Ancak insanlar istedikleri takdirde bireysel olarak veya küçük gruplarla maksimum düzeyde iyi oluşu artıracak, pozitif duyuları yaşatacak, bireyin kendisine ve diğer insanlara faydalı olacak turizm etkinliği düzenleyebilirler.

Pozitif psikoloji perspektifinden turizm ve iyi oluş/mutluluk, turizm motivasyonları gibi tartışmaları özetlemek gerekirse bu değişkenler arasında oldukça kompleks bir ilişki bulunmaktadır. Görüldüğü gibi turizm alanında mutluluğu öznel iyi oluş olarak ele alan, tatilin yaşattığ 1 hedonik duygulara ve yaşam doyumuna odaklanan araştırmalar tatil esnasında insanların duygu dururumlarının pozitif yönde değiştiğini ve yaşam doyumlarının arttığını ancak bu değişimin kısa ömürlü olduğunu göstermektedir. Turizmin uzun süreli veya kalıcı mutluluk getirip getirmeyeceği sorusuyla ilgilenen sınırlı sayıdaki çalışmada araştırmacılar dikkatlerini eudaimonik mutluluğa çevirmişlerdir. Eudaimonik veya bütüncül motivasyonların ürünü olan turizm deneyimlerinin mutluluk/iyi oluş ve yaşam kalitesine daha uzun süreli pozitif etkiye sahip olduğu

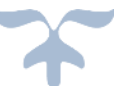


vurgulanmaktadır. Bu tür turizm deneyimleri kişinin kendini geliştirmesine, gerçekleştirmesine, yenilemesine imkân verebilir ve böylece daha kalıcı bir mutluluk tezahür edebilir.

Pozitif psikoloji sahasına turizm motivasyonları ve tercih edilen turizm türlerinin mutluluk üzerine etkisine ilişkin teoriler ve amprik çalışmaların sonuçları Müslüman turistlerin turizm motivasyonlarını değerlendirmede işlevsel olabilir. Son zamanlarda turizm sektöründe yeni yeni kendilerinden söz ettiren, sektör tarafından büyük ilgi gören Müslüman turistler çeşitli tartışmalara konu edilmektedir. Müslüman turistlerin turizm motivasyonlarını inceleyen çalışmalar yok denecek kadar azdır. Müslüman turistlerin turizm motivasyonların pozitif psikolojinin hedonik ve eudaimonik turizm sınıflaması çerçevesinde tartışmak önemli görünmektedir. Çünkü Müslümanların inanç kaynakları onları seyahate teşvik ederken aynı zamanda hangi niyetle bu seyahatleri gerçekleştireceklerine de açıklık getirmiştir. Aşağıda Müslümanların seyahatleri tarihsel açıdan yüzeysel olarak ele alınacak ardından ve günümüz Müslümanlarının turizm bağlamında seyahatleri pozitif psikolojinin hedonik ve eudaimonik turizm sınıflaması çerçevesinde değerlendirilecektir.

\section{Tarihsel Olarak Müslümanların Seyahatleri}

Müslümanlar İslam'ın ilk dönemlerinden modern zamanlara kadar başta dini, askeri, ekonomik ve ilmi nedenlerle seyahat etmişlerdir. Bu seyahatlerden dini olanlar turizm literatürünün merkezi temalarından biridir. Hatta turizm araştırmacılarına göre başta hac olmak üzere kutsal mekânlara yapılan seyahatler bugün turizm olarak adlandırılan seyahatin itici gücü ve temel kaynağı olmuştur (Jafari ve Scott, 2014). Hinduların Benares'e, Varanasi'ye, Budistlerin Lumbin, Bodh Gaya'ya Hristiyanların Beytüllahim'e, Roma'ya, Lourdes'e, Yahudilerin Kudus'e ve Müslümanların Mekke'ye yaptığı hac yolculuğu turizmin tarihi anlamda belgelenmiş en iyi kökeni olarak görülmektedir. İbadet maksadıyla kutsal mekânlara yapılan seyahatlerin turizm türü olarak değerlendirilip değerlendirilemeyeceği tartışmaları devam etmektedir. Ancak kutsal mekânları kutsal duygularla ziyarete giden bir hacı kendisini turist olarak tanımlasın ya da tanımlamasın turizm endüstrisi hacının seyahati sırasında doğan ekonomik faaliyetlerden dolayı onu turist, dini yolculuğunu ise inanç turizmi olarak tanımlamaktadır. Burada günümüz Müslümanlarının turizm tercihlerini ve motivasyonlarını değerlendirmeden Kur'an'ın seyahatlerle ilgili vurgusuna, başta $\mathrm{Hz}$. Muhammed'in ve diğer Müslümanların seyahatlerine genel bir bakış sunmak faydalı olacaktır.

Kur'an' da belirli bir amaca yönelik olan seyahatler için "seyr" kökünden kelimeler kullanılmıştır (Çağrıcı, 2009, 37/8). Aşağıda örnek olarak verilen ayetlerde görüldüğü gibi Kur'an'da teşvik edilen seyahatlerin hedefi bir diğer ifadeyle hangi motivasyona sahip olması gerektiği açık biçimde zikredilmektedir.

Journal of Analytic Divinity, https://dergipark.org.tr/tr/pub/jad Volume 4/2 
"Sizden önce(ki milletlerin başından) nice olaylar gelip geçmiştir. Yeryüzünde gezin dolaşın da yalanlayanların sonunun nasıl olduğunu bir görün." (Âl-i İmrân 3/137)

“De ki: "Yeryüzünde gezin dolaşın da (Peygamberleri) yalanlayanların sonu nasıl olmuş bir görün." (el-En'âm 5/11).

“Yeryüzünde dolaşıp kendilerinden öncekilerin sonunun nasıl olduğuna bakmadılar mı? Oysa onlar kendilerinden daha da kuvvetli idiler. Ne göklerde ne yerde hiçbir şey Allah'ı aciz bırakacak değildir. Şüphesiz $\mathrm{O}$, hakkıyla bilendir, hakkıyla kudret sahibidir." (Fâtır 35/44).

“Andolsun biz, her ümmete, "Allah'a kulluk edin, tâğûttan kaçının” diye peygamber gönderdik. Allah, onlardan kimini doğru yola iletti; onlardan kimine de (kendi iradeleri sebebiyle) sapıklık hak oldu. Şimdi yeryüzünde dolaşın da peygamberleri yalanlayanların sonunun ne olduğunu görün." (en-Nahl 16/36)

“De ki: “Yeryüzünde dolaşın da Allah'ın başlangıçta yaratmayı nasıl yaptığına bakın. Sonra Allah (aynı şekilde) sonraki yaratmayı da yapacaktır. (Kıyametten sonra her şeyi tekrar yaratacaktır) Şüphesiz Allah'ın gücü her şeye hakkıyla yeter." (el-Ankebût 29/20).

“Onlar yeryüzünde dolaşıp, kendilerinden öncekilerin sonlarının nasıl olduğuna bakmadılar mı? Allah, onları yerle bir etmiştir. İnkâr edenlere de bu akıbetin benzerleri vardır." (Muhammed 47/10).

“(Yine) onlar, yeryüzünde dolaşıp kendilerinden öncekilerin sonunun nasıl olduğuna bakmadılar mı? Onlar kendilerinden daha kuvvetli idiler. Yeryüzünü sürüp işlemişler ve orayı kendilerinin imar ettiğinden daha çok imar etmişlerdi. Onlara da peygamberleri apaçık deliller getirmişlerdi. Allah, onlara asla zulmediyor değildi. Fakat onlar kendilerine zulmediyorlardı." (er-Rûm 30/ 9).

Yukarıda verilen ayetler açık biçimde insanları seyahate teşvik edilmekte ve onların hakikatleri görmeleri, ibret almaları istenmektedir. Kimisi bütün ihtişamıyla açıkta, kimisi açığa çıkarılmayı bekleyen geçmiş milletlere ait nice kalıntılar, yaşam izleri bulunmaktadır. Sadece geçmiş milletlerin kalıntılarını değil yeryüzünün değişik bölgelerinde yaşayan insanlara, bu bölgelerin iklimine, bitki örtüsüne, hayvanlarına şahit olmak, onları tanımak evrenin düzeni işleyişi hakkında bilgi sahibi olmak önce insanın kendisini sonra Allah'1 layıkıyla tanımaya götüren vasıtalardır. Elmalı Hamdi Yazır (2000) Ali İmran Suresi 137. ayetin tefsirinde "geziniz" emrinin, yalnız izin verilen ve yapılmasında dinen sakınca olmayandan (mübah) ziyade, en az teşvik edilen (mendûb), iyi ve güzel kabul edilen (müstehab) bir emir olduğunu ifade etmekte ve benzer ayetlerin Müslümanları tarihi arkeolojik araştırmalar yapmaya teşvik ettiğini de belirtmektedir. 
Hz. Muhammed'in hayatında çok sayıda seyahat yaptığı bilinmektedir. Hz. Muhammed gençliğinde ve yetişkinliğinde ticaret maksadıyla seyahat etmiştir. Peygamberliği zamanında Mekkeli müşriklerin baskı ve eziyetlerinin artmasıyla Müslümanların güven içinde yaşayabilecekleri bir yurt edinebilmek için ilkin Taif'e ve daha sonra Medine'ye yolculuk yapmıştır. Müslümanların güvenliklerini tehdit edenlere karşı askeri seferlere katılmıştır. Ayrıca Hac ibadetini gerçekleştirmek için Medine'den Mekke'ye gitmiştir. Hz. Muhammed'in tüm seyahatleri ticari, askeri, dini olmak üzere zorunlu gerekçelerle gerçekleşmiştir.

Hac, Müslümanların tarih boyunca en önemli seyahat nedeni olmuştur. Gücü yeten her Müslümanın yerine getirmesi gereken hac, Hz. Muhammed döneminden beri Müslümanların gerçekleştirdiği en sistemli seyahattir. Bu gün üç milyondan fazla insan dünyanın çeşitli yerlerinden Allah'ın çağrısına icabet ederek kitlesel biçimde Mekke'ye gelmektedir.

İslam tarihinde görülen bir diğer önemli seyahat türü ilim için yapılan seyahattir. Müslümanlar Hz. Muhammed'in sözlerini doğru kaynağından öğrenmek için ilk dönemlerden itibaren seyahat etmişlerdir. Bu seyahatler "rihle" olarak isimlendirilmiştir. Bunun dışında İslam âlimleri daha çocukluk yıllarından itibaren meşhur olan âlimlerden eğitim almak ve daha sonra da eğitim vermek için birçok şehir gezmişlerdir. Müslümanlar coğrafya, tarih, kültür konularında bilgi toplamak için de seyahatler yapmışlardır. Kitâbü'lBüldân'ın yazarı Ya'kūbî ilk coğrafyacılardandır. O, Cezayir, Ermenistan, Filistin, Hindistan, Horasan, Mısır gibi ülkelere seyahatler yapmıştır. Bir diğer coğrafyacı İbn Havkal'dir. İbn Havkal'in Kitâbü Șûreti'l-arż (el-Mesâlik ve'l-memâlik) başlıklı eseri de otuz dört yıllık seyahatin ürünüdür. Ayrıca sûfiler de seyahati insan ruhunu besleyen, manevi olarak geliştiren bir araç olarak görerek farklı şehirler, bölgeler dolaşmışlardır (Çağrıc1, 2009, 7-9).

Bunların dişında az sayıda olmakla birlikte merak, keşif amacıyla seyahat eden Müslümanlar da olmuştur. Bunlara İbn Battûta, İbn Cübeyr, Nâsırı Hüsrev, Evliya Çelebi örnek verilebilir. İbn Battûta hac için yola çıkmış, hac ibadetini gerçekleştirdikten sonra 29 sene boyunca seyahat etmiştir. Orta Doğu'ya, Afrika'ya, Uzak Doğu'ya gitmiş yani Avrupa hariç eksi dünyanın tamamını gezmiştir. Bu da onu Ortaçağın iki büyük seyyahından biri yapmıştır (Aykut, 1999, 19/361-368). Bir başka isim İbn Cübeyr' dir. İbn Cübeyr de sıra dışı bir hac yolculuğu yapmıştır. 1138 yılında Granada'dan yola çıkmış İskenderiye, Kahire, Mekke, Medine, Bağdat, Sâmerrâ, Dımeşk, Filistin gibi Doğunun pek çok önemli şehrini iki yılda gezmiştir (Karaarslan, 1999, 19/400-402). Bir başka seyyah İsmaili Şiilerinden olan ve Nâsır-1 Hüsrev ismiyle tanınan Ebû Muîn Nâsır b. Hüsrev'dir. O da İbn Cübeyr gibi hac yapmak için yola çıkış bu yolculuğunu yedi yılda tamamlanmıştır (Azamat, 2006, 32/395397). Son olarak büyük Türk seyyahı Evliye Çelebi' yi de anmak gerekir. 1630'te başlayarak ömrünün sonuna kadar Kuzey Afrika, İran, Kafkaslar, Orta ve Kuzey Avrupa'yı dolaşmış,

Journal of Analytic Divinity, https://dergipark.org.tr/tr/pub/jad Volume $4 / 2$ 
kültür tarihinde eşine rastlanmayan bir seyahatname kaleme almıştır (İlgürel, 1995, 11/529533).

Müslümanların seyahat nedenlerinden biri de sıhhat bulmak, hastalıklara şifa aramaktır. Müslümanlar şifa bulmak için bimaristanlara, şifahanelere, termal su kaynaklarına gitmiştir. Bağdat, Fas, Kurtuba, Grrnata gibi şehirlerde kurulan hastanelere ve tıp fakültelerine hem Müslüman hem de gayri Müslim çok kişi için tedavi için seyahat etmiştir. Bu seyahatlerin bugünkü anlamiyla tam bir sağlik turizmi olduğu ileri sürülmektedir (Tontuş, 2015).

İslam'ın ilk dönemlerinden beri Müslümanlar dinî, ilmi, ekonomik, askeri, sağlık gibi nedenlerle seyahat etmişlerdir. Yakın zamanlarda Müslümanlar bir başka seyahat türü ile tanışmıştır. Tatil amaçlı seyahat. İslam dünyasında Müslümanların çoğu hedonik tüketim alanı olarak gördükleri tatile uzun bir süre hayli mesafeli durmuşlardır. Ancak yaklaşık son 30-40 yıldır Müslümanların dinlenme eğlenme amaçlı kitle turizmine yönelik tutumları değişim göstermiştir.

Günümüz Müslümanları özellikle ekonomik durumlarının iyileşmesiyle, alım güçlerinin artmasıyla yeni yeni turizm pazarında yer almaya başlamıştır. Müslüman turistler küresel turizm pazarının keşfedilmesi gereken verimli bir niş pazarı olarak görülmektedir. MasterCard Müslüman Milenyum Seyahat Raporu 2017'ye (MMTR, 2017) göre, 2016 yılında 121 milyon Müslüman seyahat etmiş ve 156 milyar ABD doları harcamıştır. Yine MasterCard - CrescentRating' in 2019 yılında yayımladığı Global Muslim Travel Index'e göre; 2000'de bir başka ülkeye giden Müslümanların sayısı 25 milyonken, 2018'de bu sayı 140 milyona ulaşmıştır. Araştırma 2026 yılında bu sayının 230 milyona ulaşacağını ve Müslümanların turizm harcamalarının 300 milyarı aşacağını tahmin etmektedir.

İslam İşbirliği Teşkilatı Ekonomik ve Ticari İşbirliği Daimi Komitesi tarafından hazırlanan rapora göre (COMCEC, 2016) Müslümanların seyahatlerinin \%75'ini tatil/boş zaman türü seyahatler oluşturmaktadır. Yaklaşık \%10'unu ise Hac ve Umre seyahatleri oluşturmaktadır. İş seyahati yüzde 9 ila 10 civarındayken, tıbbi veya sağlık nedeniyle yapılan seyahat \%1'den daha azdır. Mastercard (MTSI) 2015 raporunda da benzer ifadelere yer verilmiştir. Müslüman gezginlerin büyüyen orta sınıfı için seyahatlerin başlıca nedeni plaj tatillerini kapsayacak biçimde dinlenme, eğlenme, alış veriş ve yemektir. MTSI 2015'e göre, Müslüman gezginler alışverişte 32 milyar dolar harcamış, seyahat ederken 25 milyar doları ise yemeye ayırmıştır. MTSI'nın 2017 yılı araştırmasında da katılımcılardan seyahat nedenlerini bir veya daha fazla seçenekle belirtmeleri istenmiştir. Seyahat nedeniz nedir sorusuna katılımcıların \%93’ü boş zaman/tatil, \%63'ü yerlileri ve kültürlerini tanımak, $\% 43^{\prime} \ddot{u}$ akrabaları ve arkadaşları ziyaret, \%30'u özel faaliyetlere ve festivallere katılmak, 
$\% 25^{\prime} \mathrm{i}$ iş, \%22'si din ve maneviyat, \%10'u sağl1k/iyi oluş, \%8'i gönüllü turizmi, \%4'ü ise diğer cevabını vermiştir.

\section{Günümüz Müslümanlarının Seyahat Motivasyonlarını Pozitif Psikoloji Perspektifinden Değerlendirme}

Turizm veya dini bilimler alanında, turizm ve İslam ilişkisine odaklanan çalışmaların çoğunda yukarıda örnekleri verilen Kur' an ayetlerine, Hz. Muhammed'in seyahatlerine ve seyahat hakkındaki sözlerine ayrıca İslam tarihinde Müslümanların sair seyahatlerine dikkat çekilerek İslam'ın turizmi teşvik ettiği ileri sürülmektedir. İslam ve turizm arasında bir gerilim olmadığı, İslam'ın turizmi yasaklamadığı, Müslümanların Müslüman olan veya olmayan ülkelere seyahat edebilecekleri ve kendi ülkelerine de başka ülkelerden, dinlerden insanların gelebileceğine izin verdiği vurgulanmaktadır (Süt, 2014; Zamani-Farahani Henderson, 2010; Arasteh - Eilami, 2011, Dinçer - Bayram, 2017). Turizmin bugün kazandığı geniş anlam çerçevesi göz önüne alındığında Müslümanları ve turizmi ayrı düşünmek neredeyse imkânsızdır. Başta Hac olmak üzere tarih, kültür, aile-akraba ziyareti gibi nedenlerle yapılan seyahatlerde ulaşım, konaklama ve yeme-içmeden doğan tüm hizmetler turizm sektörü tarafından verildiği için Müslümanlar birçok seyahatleriyle turizm faaliyetlerinin doğal öznesi konumundadır. Ancak Kur'an'ın seyahatle ilgili olan ayetlerini veya Hz. Muhammed'in seyahatle ilgili sözlerini kendi semantik bağlamlarından kopartarak turizmin en yaygin şekli olan kitle turizmine dinî referans olarak kullanmak tartışmalı bir durumdur. Bu elbette kitle turizminin veya dinlenme, eğlenme amaçlı turizmin dinen yasaklandığı iması taşımamaktadır. Genel olarak İslâmî ölçülere uyduğu takdirde dinlenme, eğlenme amaçlı seyahatlerin gerçekleştirilebileceği kabul edilmektedir. Burada üzerinde durulan husus Kur'an'in ve Hz. Muhammed'in teşvik ettiği seyahatlerin düşünme, akletme, takdir etme, hayranlık duyma, şükretme, paylaşma gibi erdemlere ulaşmaya aracılık edecek türden seyahatler olmasıdır. Bu seyahatlerin altında yatan itici gücün ise hedonik motiveler değil bir anlam ve amaca ulaştıracak eudaimonik motiveler olduğu rahatlıkla söylenebilir.

Yukarıda Müslümanların seyahat nedenlerine ilişkin verilen rakamlar dünya turizm pazarına geç girmelerine rağmen bu pazarda çok hızlı yükseliş gösteren Müslümanlar için turizmin büyük oranda tatil bir diğer ifadeyle hedonik tüketim anlamina geldiğini göstermektedir. Bugün Müslüman turistlerin büyük bir kısmı tatilde dinlenme, eğlenme, alışveriş etkinliklerine yönelmekte, onları beş yıldızlı oteller, plajlar, lüks AVM'ler gibi mekânlar daha çok cezbetmektedir. İslami turizm, Müslüman dostu turizm veya helal turizm kavramları altında Müslümanların turizm faaliyetlerinin isimlendirilmesi tüketim ağırlıklı kitle turizminin hedonik doğasını değiştirmemektedir. Tatil köyü veya otel turizminin insanlara haz dişında verebileceği fazla bir şey yoktur. İslamî temalı otel, tesettür otel vb. isimlendirmelerle hizmet veren yerlerin pazar politikası konaklatma, eğlendirme, yedirme-içirme, gezdirme ve para harcatmaya dayalıdır.

Journal of Analytic Divinity, https://dergipark.org.tr/tr/pub/jad Volume 4/2 
Bazı araştırmacılar İslamî turizm veya Müslüman dostu turizm kavramlarıyla tanımlanan turizm anlayışını Batılı yaşam biçimin ürünü olan hedonik turizme alternatif olarak görmektedir (Timothy - Iverson, 2006). Hedonik turizm formu, hedonizmin felsefi ve psikolojik kavramsal çerçevesi daraltılarak sadece alkollü içeceklere, kumara, disko-bar eğlencesine veya yabancılarla seks eylemlerine indirgendiği takdirde (Bkz. Moghavvemi, 2019) haklı olunabilir. Veya İslamî turizm, Kur'an'ın önerdiği motivasyonlarla seyahat etmeyi, doğal çevreye zarar vermemeyi, kaynakları israf etmemeyi ima ettiği takdirde hedonizme alternatif bir turizm anlayışı olabilir. Ancak kitle turizminin müşterisi olan Müslüman turistler belirli dini kısıtlamalar içinde olsa da turistik eylemlerini çoğunlukla nihai anlamda hazza ulaşacak biçimde düzenlemektedir. Müslümanların kaldıkları sahil otellerinde alkollü içeceklerin olmaması, kumar, gece kulübü eğlencelerinin olmaması onların motivasyonların hedonik olmaktan çıkarmamaktadır. İslami veya helal konsept başlığı altında hizmet veren otelleri tercih eden turistlerin beklentileri İslam temalı olmayan otelleri tercih eden kişilerin beklentileriyle büyük oranda örtüşmektedir. Örneğin en az dört yıldızı olan ve hizmet kapasitesi yüksek tatil tesisi anlamına gelen resort otelleri tercih eden müşterilerin beklentileri üzerine yapılan bir araştırmada beklentiler otel olanakları, oda olanakları, otelin konumu, deniz-sahil, havuz, hizmet kalitesi temaları altında toplanırken (Güzel - Güzel, 2006), İslâmî temalı otellerde yine müşteri beklentileri üzerine yapılan bir araştırmada da müşretilerin beklentileri; otelin konumu, oda olanakları, yemeiçme olanakları, hizmet kalitesi, personel ve boş zaman etkinlikleri temaları altında toplanmıştır. Ancak İslâmî temalı otellerde seviyeli/açık olmayan etkinliklerin yapılması, kadın ve erkek alanlarının (restaurant, cafe vb.) ayrı olması, kadın ve erkek havuzlarının ayrı olması, kadınlara özel hizmet sunulması, kadınlar bölümünde mahremiyete özen gösterilerek telefon ve kameraların içeriye alınmaması gibi hassasiyetler de öne çıkmıştır (Güzel - Güzel, 2017). Yine helal konsept otellere yönelik müşteri şikayetlerinden müşterilerin daha lüks, daha rahat, daha eğlenceli bir hizmet bekledikleri anlaşılmaktadır (Kargiglioğlu vd. 2017). Kısaca bir tatilin veya turizm faaliyetinin İslâmî veya helal kavramı ile etiketlenmesi onların hedonik olmadığını iddia etmek için yeterli görünmemektedir.

Bazı turizm türlerinin insanlara haz dışında hemen hemen verebileceği bir şey yokken bazı turizm türleri de insanlara çok farklı şeyler verebilir. Örneğin deniz-kumgüneş üçlüsü ile tanımlanan dinlenme eğlenme amaçlı tatil turizmi, popüler eğilimlerle orayı gördüm, burada bulundum diyebilmek için yapılan taklit turizmi, gösteriş, statü kazanmak için yapılan turizm, lüks alışveriş amaçlı turizm büyük oranda hedonik bir motivasyonun ürünüdür. Özellikle her şey dâhil sistemle işleyen otellerde yapılan tatiller hedonik tüketim üzerine kuruludur. Otel turizminin bir takım dini ölçüler içinde bile olsa yeme, içme ve zevk, eğlenme dışında müşterisine ne yazık ki verebileceği fazla bir şey yoktur. Öte taraftan turizm alanında yapılan pozitif psikoloji araştırmaları kültür turizmi, inanç turizmi, kongre turizmi, gönüllü turizmi, inziva turizmi, hüzün turizmi, ölüm 
turizmi, hatta doğa sporları gibi turizm türlerine insanların daha çok eudaimonist motivasyonla yöneldiğini göstermektedir (Filep, 2009). Doğal ve tarihi kültür varlıklarını tanıma, farklı kültürlerin geleneklerini, göreneklerini tecrübe etme imkanı veren kültür turizminin zihinsel anlamda bir gelişim sağlama, kültür düzeyini, bilgi birikimini artırma potansiyeli vardır. Doğa sporları turizminde turistler yaşam boyu sürecek bir tutku geliştirebilir ve fiziksel ve zihinsel sınırlarını zorlayabilirler. Dünyanın gelişmemiş bölglerinde muhtaç insanlar için düzenlenen yardım gezileri, buralarda yaşayan insanlara faydalı olacak gönüllü çalışma gezizileri alturistik bir forma sahiptir. Yine kendini gerçekleştirme, keşfetme amacıyla yapılan inziva turizminde insanlar kendi yaşamlarına odaklanma, kendileriyle başbaşa kalma, sahip olduklarını fark etme, şükretme fırsatını yakalayabilirler (Simith - Diekman, 2017). Hüzün turizmi, kara turizm, ölüm turizmi temaları altında gerçekleştirilen turizmde ise savaşların, işkencelerin, ölümlerin meydana geldiği yerler insanlarda hüzün duyusunu ortaya çıkarır. Acının, ölümün, işkencenin yaşandığı yerlerde, mekanlarda kalan sembolik unsurların tarihsel hafızayı tazeleyici, milli, insani kimliği kuvvetlendirici gücü vardır. Bu tür turizimde hedonik veya subjektif iyi oluştaki gibi hazzı yaşama, acıdan kaçma prensibinin aksine hüznün, acının üzerine gitme ve ona katlanabilme vardır. Genel olarak eudaimonik olarak isimlendirilerilen bazı turizm türleri İslami öğreti ile çelişmemekte ve bazıları ise bizzat teşvik edilmektedir. Öte taraftan insan doğasının karmaşası diğer davranışlarına yansıdığı gibi turizm davranışlarına da yansımaktadır. Bir seyahati hedonik veya eudaimonik karaktere bürüyen turizm türünden öte turstin motivasyonu daha geniş anlamda niyetidir. Csikszentmihalyi ve Coffe'nin (2017) kuramlarında belirttikleri gibi iki turist farklı motivasyonlarla aynı turizm türünde buluşacakları gibi, aynı motivasyonla farklı turizm türlerine yönelebilirler. Örneğin savaş turizmi teması altında farklı motivasyonlara sahip olan kişiler bir araya gelebilir. Aktif savaş bölgelerine bir kişi savaş mağdurlarına yarım etmek için seyahat edebilir, bir başka kişi ise tamamen macera amaçlı, bir aksiyon filmini gerçek hayattta izleme gibi çok hedonik bir motivasyonla binlerce dolar ödeme yaparak seyahat edebilir. Hac veya Umre seyahatleri de farklı motivayonlara sahip insanları bir araya getirebilir. Bir müslüman umresini "hac ile umreyi Allah için tam yapın" (Bakara, 2/196) ayeti buyruğunca sadece Allah'ın rızasını kazanmak, ruhen arınmak, temizlenmek ve yenilenmek amaciyla gerçekleştirirken, başka bir müslüman ise hem ibadet etmek hem de ancak seküler bir tatil turizminin vadettiği zevki ve rahatlığı yaşama arzusuyla umreye gidebilir. Beş yıldızlı otellerde sınırsız hizmetten yaralanmayı, konforlu araçlarla rahat yolculuk geçirmeyi, en iyi manzaraya sahip odalarda konaklamayı ve kendini ayıcalıklı, özel hissetmesini sağlayacak, unutulmayacak bir deneyim yaşamayı arzu edebilir. Bu vaatler seküler bir tatilin insanlara sunduğu tipik hedonik vaatlerdir. Yüzeysel bir bakışla farz olan Hac veya Hz. Muhammmed'in sünneti olan Umre gibi kutsal bir yolculuğu tipik bir turizm tatili ile bir arada düşünmek mümkün görünmese de kişilerin sahip olduğu motivasyon onu hedonik veya eudaimonik karaktere büründürebilir. Ancak yine Csikszentmihalyi ve Coffe'nin (2017) kuramında belirttiği gibi seyahatlerin dinamik bir doğaya sahip olduğunu

Journal of Analytic Divinity, https://dergipark.org.tr/tr/pub/jad Volume $4 / 2$ 
unutmamak gerekir. Örneğin arkadaş tavsiyesi ile Afrika'ya yardım gezisine dâhil olan bir kişinin tamamen dışsal bir motivasyonu içsele, can sıkıntısından kurtulma, bir değişiklik yapma isteği gibi hedonik bir motivasyonu spitrütel bir motivasyona dönüşebilir. Hatta bu kişi gittiği yerde bir müddet yaşamaya, insanlara daha fazla yardım etmeye karar verebilir.

Turizm ve pozitif psikoloji literatürünün gösterdiği üzere turizm ile mutluluk, iyi oluş ilişkisine odaklanan çalışmalar hangi tür motivasyonla hareket edilirse edilsin turizm deneyiminin insanlara olumlu duygular yaşattığına işaret etmektedir. Turizm deneyimi olumlu duyguları güçlendirmekte, en azından bu deneyim sürecinde olumsuz duyguların azalmasını sağlamaktadır. Olumlu duygular yaşamak, keyifli olmak herkes için önemlidir. Turizm sektörünün temel amacı daha çok tükettirmek ve daha çok kazanmak olsa da Müslüman olsun ya da olmasın çoğunlukla turistler kendilerini daha iyi, daha mutlu hissetmek için turizme yönelmektedir. Müslümanların da dinlenmeye, rahatlamaya, olumlu duygular yaşamaya ihtiyaçları vardır. Ancak Müslüman bir turist aldığı zevkin, keyfin hayatının anlamına katkısıyla birlikte doğaya maliyetini de hesaba katmak durumundadır. Müslüman bir turist basitçe dinlenme, eğlenme, macera, hatta doğal yaşamı tecrübe etme adına pazarlanan paket turizm programlarının sanıldığı kadar naif bir deneyim olmadığının, doğal ve kültürel çevreye ait her unsurun tüketim nesnesi haline getirildiğinin, toplumsal ve çevresel olarak yarattı̆̆ tehlikelerin bilincinde olmalıdır. Birçok turizm faaliyetinde turistin yaşayacağı hazza ve sektörün kazanacağı ekonomik kazanca karşılık ne yazık ki eko sistem zarar görmekte ve doğal kaynaklar katledilmekte veya israf edilmektedir. Müslüman turist helal yiyecek, içecek, otelde mescit ve kadın erkek ayrı havuz, plaj gibi konularda gösterdiği hassasiyet kadar satın aldığı hizmetin kendine gelinceye kadar hangi aşamalardan geçtiğine bu süreçte doğal çevreye ne tür etkide bulunduğuna dikkat etmelidir. Yaşanan kısa süreli hazzın bedeli ve hedonik bir tüketimin insan mutluluğu üzerindeki geçici etkisi göz önüne alındığında Müslümanların eudaimonik veya hatta Smith, Diekmann (2017) işaret ettiği sürdürülebilir ve alturistik turizm formlarına yönelmeleri daha iyi bir tercih olacaktır.

Müslüman turistler hangi motivasyonla seyahat ettiğini ve hangi kazanıma ulaşmayı istediğini, bu kazanıma götürecek araçları iyi bilmelidir. Smith ve Diekmann (2017) belirttiği gibi önceden oluşturulmuş, standart paket turlarla eudaimonik hedeflere ulaşmak imkânsız olmasa bile çok zordur. Çünkü yaşam tarzı turizmi gibi bazı turizm türleri dışarıda bırakılırsa turizm sektörü maddi manevi her şeyi paraya çevirmeyi amaçlamaktadır. Seyahatini iyi planlamayan bir kişi eudaimonsit bir deyim yaşama motivasyonuyla hareket ederken bile tuzağa çekilmiş, kapitalizmin karını artırmak için ürettiği kurgusal yaşamların, metaya çevrilmiş kültürlerin özensiz tüketicisi konumuna düşülebilir. Örneğin standart bir tatil paketi ile 7 günde 5 ülke tarzında yapılan seyahatlerde gidilen ülkelerin kültürünün, felsefesinin, yaşam biçimlerinin içine girmek, o 
yerlerin insanları ile etkileşime girmek mümkün değildir. Yapılan şey sadece göstermelik bazı simgesel yerlerin ve objelerin yanında bir fotoğraf çekme zamanı kadar kalıp devam etmektir. O halde Müslüman turistler bu seyahatlerde sadece bir müşteri mi olmak istediklerine ya da bilgilenmiş, öğrenmiş, maddeye ve manaya bakış açısı gelişmiş bir biçimde sonuç almak istediklerini düşünmeli, değerlendirmelidirler.

Haz odaklı faaliyetlerin kaçınılmaz olarak hedonik adaptasyonu (Brickman Campbell, 1971) getirdiği gözden kaçırılmamalıdır. İlk kez deneyimlendiğinde büyük haz veren turizm faaliyetleri zamanla mutlu etmeyecektir. Çünkü tüketimin hedonik değirmenine kapılmak bir müddet sonra pozitif duyguları da yaşanmaz kılabilir. Mutluluk seviyesini korumak veya daha yüksek bir seviyeye getirmek için daha fantastik, daha maceracı faaliyetlere yönelinecektir. Ancak Müslümanların inançları başta olmak üzere hareket alanlarını kısıtlayacak pek çok unsur bulunmkatadır. Müslüman turistler turizm tercihlerinde dinî-manevi, insani anlamda gelişimi hedefleyerek kendilerini popüler eğilimlerle hedonik motivasyonların sınırlı dünyasına hapsetmemelidir. Çünkü Kur'an'da Müslümanların teşvik edildiği seyahatler eudaimonik özelliktedir. Müslümanların yeryüzünün çeşitli yerlerinde geçmiş millerin izlerini görmek, Allah'ın yaratma kudretine şahit olmak, insanlarla ilişki kurmak, onları tanımak veya yardım etmek amacıyla yapacağı seyahatler eudaimoniktir. Eudaimonik seyahatlerin pozitif duyguları yaşamaya engel olduğu söylenemez. Ancak eudaimonik seyahatlerde haz bir amaç değil, anlamlı faaliyetlerin sonucudur. Batı dünyasında yapılan çalışmalar insanların materyalizm ve tüketicilik kaynaklı memnuniyetsizliklerinin neticesinde daha iyi ve anlamlı bir yaşam arzusuyla alternatif turizm türlerine yöneldiklerini göstermektedir. Yeoman (2008) 2030'ların turizm dünyasını tasvir ettiği çalışmasında bu tarihlerde insanların turizm deneyimlerinin haz odaklı değil daha çok anlam odaklı olacağını ifade etmektedir. Yeoman'a göre turistlerin sağlıklı yaşam, kendini gerçekleştirme vb. alanlarda talepleri artış göstermektedir. Ayrıca Avrupalıların çevresel konularda gittikçe artan farkındalık ve duyarlılıklarıyla seyahat etme arasına bir çelişki yaşadıklarını, bu çelişkiden kurtulmak için gelecekte karbon salınım dengesini sağlayacak, sürdürülebilir seyahat ürünlerine rağbet edeceklerini ifade etmektedir. Bu nedenle turizm sektörü yeni ürünler geliştirerek, yeni niş alanları oluşturarak bu taleplere cevap vermeye çalışacaktır. Yeoman Doğu toplumlarında refah düzeyinin artmasıyla turizm pazarında fazla sayıda yer alacaklarını ancak tüketim tercihlerinin Batılı insanlardan farklı olacağını ileri sürmektedir. Zenginleşmeye başlayan Doğulular yeme içme, lüks harcama, dinlenme eğlenme gibi hedonik tatilleri tercih ederken, nispeten belirli düzeyde zenginliğe ve yüksek yaşam standardına sahip olan Batı Avrupalıların daha çok deneyim, kendini gerçekleştirme fırsatı sunan tatilleri tercih edeceğini iddia etmektedir. Ona göre İngiltere gibi ülkelerde herkes kişisel gelişim için zaman ve çaba sarf etmenin önemli olduğunu kabul etmekte, gönüllü turizmini kendini gerçekleştirmenin bir yolu olarak görmekte, gezegeni kurmak için çeşitli projelerin içinde yer almakta veya Afrika'da gönüllü bir projeye katılmaktadırlar. Gönüllü turizmi

Journal of Analytic Divinity, https://dergipark.org.tr/tr/pub/jad Volume $4 / 2$ 
turistlerin iyi ve anlamlı işler yaptıklarını hissettirecek temelinde fedakarlığın yer aldığı kitlesel bir pazar haline gelmektedir.

Bugün Yeoman'ın ön görülerinin desteklendiği görülmektedir. Refah düzeyi yükselen Müslümanların önemli bir kısmı hedonik turizm türüne yönelmektedir. Turizm konusunda Müslümanlardan daha eski tecrübeye sahip olan Batılılar kitlesel olarak hedonik talep ve üretime dayalı turizm anlayışını yavaş yavaş terk ederken Müslümanların herhangi bir ideal, anlam ve amaç taşımayan, sadece zevk ve sefa vadeden turizmin sadık müşterileri olmamaları gerekir. Müslümanlar, Kur'an'da seyahatin hangi amaçlarla yapılması gerektiğini, sahada hangi tür turizm tercihinin insanların mutluluk düzeyini daha olumlu etkilediğini ortaya koyan çalışmaları dikkate alırlarsa maddi ve manevi gelişimi, kendini gerçekleştirmeyi sağlayacak, sürdürülebilir, doğal çevreyle uyumlu kendilerine özgü, inanç kaynaklarıyla çelişmeyecek, Batının ürettiği yaygın kitle turizmine alternatif bir turizm anlayışını ve hizmet sektörünü geliştirebilirler. Özellikle Türkiye bu konuda büyük bir potansiyele sahiptir. Yeoman (2008) 2030'a gelindiğinde, Türkiye'nin, Hristiyanlık ve İslam'ın kesişme noktasında, "Avrupa turizminin tacındaki mücevher" olacağını, uluslararası girişlerin yılda \%6 oranında büyüyeceğini ve 20,3 milyondan 90,8 milyona çıkacağını öngörmektedir. Aynı zamanda, gelirlerin yıllık \% 5.9 artışla 18.2 milyar ABD dolarından 78.6 milyar ABD dolarına yükseleceğine inanmaktadır. Yeoman, Doğu ile Batının kavşak noktası olan Türkiye'nin turizm sektörünü ağırlıklı olarak her şey dâhil tatil köylerinden geniş bir alana yayması, tarih, kültür, doğa yürüyüşü, kayak, su turizmi ve kırsal turizmini de geliştirmesi gerektiğine inanmaktadır. Başta Türkiye ve diğer turist kabul eden Müslüman ülkeler hedonik turizm formuna alternatif çok çeşitli turizm zenginliğine sahiptir. Bu nedenle maddi ve manevi anlamda bu zenginlikleri en iyi şekilde değerlendirmesi gerekmektedir.

Öte yandan Müslümanların günümüz dünyasında eudaimonik hedeflerle seyahat etmesi için birçok neden bulunmaktadır. Örneğin gönüllü turizmiyle sıkıntı içinde yaşan Müslüman beldelere gidip, buradaki Müslümanlarla sahip olunan zenginlikler paylaşabilir. İnsanlara turizm dışında yardım etmenin başka yolları elbette bulunmaktadır. Ancak bu tür seyahatler zorluklar içinde yaşayan insanlara umut kaynağı olabilir. Ayrıca ne kadar küçük ölçekli olursa olsun bu bölgelere yapılacak seyahatlerden doğan ekonomik faaliyetler insanların güçlenmelerine katkı sağlayacaktır. Müslümanların konfor alanlarını daha konforlu ve lüks yerler için değil de insanlara yardım için terk etmeleri kendilerine yaptıkları en büyük iyilik olacaktır. Çünkü pozitif psikolojiye göre iyilik, anlamlı bir şey yapma hissi pozitif duyguları daha fazla açığa çıkarmakta, negatif duyguları azaltmaktadır.

Eudaimonik motivasyonlu alternatif turizmler Müslüman turistlerin fiziksel ve mental sağlığını olumlu etkileyecektir. Gündelik hayatta daha çok rutinler hâkimdir. Ancak bu rutinler insanların kendini yenilemesine, keşfetmesine, sahip olduklarına minnet 
duymasına, güzel olan şeylere karşı takdir, erdemli olan davranışlara karşı hayranlık duymasına, iyimser olmasına engel olabilir. Müslümanların seyahat etmesi bu gibi olumsuzlukları tersine çevirmeye yardımcı olabilir.

Seyahatin Müslümanlar için bir başka pozitif etkisi, Müslümanların yaşamadıkları veya az oldukları bölgelerde Müslümanlara yönelik ön yargıların kırılmasına yardımcı olmasıdır. 11 Eylül'den beri Batı dünyasında yükselen İslamofobi nedeniyle Müslümanlar ayrımcılığa maruz kalmaktadır. Müslümanlar, dünyanın sınırlı bir coğrafyasına sıkıştırılmış, geri kalanı ile bağlantısı kopmuş bir yaşam sürmeyerek dünyanın bir parçası olduklarını tüm dünyaya yayılan seyahatleriyle gösterebilirler. Müslümanlar, turizm seyahatlerini İslam'ın inceliğini, yardımseverliğini dünyaya tanıtmanın bir vasıtası olarak kullanabilirler.

\section{Sonuç}

Bu çalışmada, pozitif psikoloji perspektifinden turizm motivasyonları literatüründeki mevcut çalışmalar kapsamında incelenmiş ve bu bakışla Müslümanların turizm dünyasındaki motivasyonları, motivasyonların mutluluk üzerindeki olası etkileri tartışma konusu edilmiştir.

İnsan doğasının karmaşıklığı ve dinamikliği turizm sahasına da yansımaktadır. Tarihin eski dönemlerinde insanlar belirli ihtiyaçları gidermek için seyahat etmişken, modern dünyada insanların birincil seyahat nedeni turizmdir. Mutluluk bilimi olarak da isimlendirilen pozitif psikoloji insanların temelde daha mutlu olmak, daha iyi hissetmek için yöneldikleri turizm deneyimlerini, motivasyonlarını ve turizmin mutluluk üzerindeki etkisini yakın bir zamanda mercek altına almıştır. Sınırlı sayıda olmakla birlikte yapılan araştırmalar hedonik turizm formunun mutluluk üzerindeki pozitif etkisinin tatil süresiyle sınırlı olduğunu, eudaimonik turizm formunun ise daha uzun süreli ve kalıcı bir pozitif etki yarattığını göstermektedir.

İslam dini hem dünya hem de ahiret saadetine ulaştıracak vasitalardan biri olması nedeniyle Müslümanları seyahat etmeye teşvik etmektedir. İslam'ın zevk alma, dinlenme, rahatlama amaçlı bir seyahati yasakladığını söylemek zor olsa da, teşvik ettiği seyahatlerin temel motivasyonun eudaimonik olduğu rahatlıkla söylenebilir. Müslümanların dünyanın en önemli endüstrilerinden biri olarak görülen turizm endüstrisinde alternatif bir anlayış geliştirebilmelerinin, dünyaya örnek olabilmelerinin yolu Kur'an'ın insanlara seyahati neden önerdiğini iyi anlamaktan geçmektedir. Seyahat yapabilecek maddi olanaklara sahip Müslümanların Batı́nın geliştirdiği ve yaydığı hedonik tüketim turizminin sadık müşterileri olmak yerine hem kendilerinin hem de diğer insanların maddi manevi gelişimlerine yardım edecek turizm alanlarına daha çok yönelmeleri faydalarına olacaktır. Ayrıca Müslüman turistler ve turizm sektörü alternatif turizm anlayışı ve türleri geliştirmelidir. Müslümanların alternatif bir turizm felsefesi geliştirebilecek dini, ahlaki ve felsefi kaynakları bulunmaktadır. Ancak bugün İslami turizm, Müslüman dostu turizm,

Journal of Analytic Divinity, https://dergipark.org.tr/tr/pub/jad Volume 4/2 
helal turizm gibi kavramlar ekseninde yapılan tartışmaların bu alternatif turizm anlayışını geliştirebilecek zeminden oldukça uzak olduğu görülmektedir. Yapılan tartışmalar temel motivasyonu itibariyle hedonik turizm formu içinde bir takım dini ölçülerle çelişmeden tatillerin nasıl yapılacağı, otellerin nasıl işletileceği, müşterilerin nasıl memnun edileceği ile sinırlıdır. İslami turizm; otel odalarında kıble işaretinin olmasına, seccade tespih bulundurulmasına, alkol olmamasına, helal yiyeceklere, kadınlar ve erkekler için ayrı havuzlara veya sahillere indirilmektedir. Oysa turizm Müslümanlar tarafından dini, ahlaki, felsefi açıdan daha geniş bir zeminde tartışılmalı, Müslümanların turizm sahasında temel seyahat motivasyonlarının neler olması gerektiği sorusu farklı disiplinler tarafından sorulmalı ve Müslümanların turizm deneyimlerinin mutlulukları üzerine etkisi çok boyutlu olarak incelenmelidir.

Pozitif psikoloji perspektifiyle çoğunluğu Avrupa ve İskandinav ülkelerinde yapılan araştırmalar bir anlam ve amaç taşıyan turizm deneyimlerinin turistlerin mutluluk düzeylerini daha çok artırdığını göstermektedir. Müslüman olmayan örneklemlerde bu çalışmalar gerçekleştirilse bile psikolojik açıdan insan davranışlarının temel dinamikleri, hazın geçici olduğu öte yandan huzurun ve kalıcı mutluluğun anlamlı eylemler neticesinde kazanıldığı gerçeği göz önüne alındığında Müslümanların eudaimonik turizm motivasyonlarına sahip olmalarının ve bunu getirecek turizm türlerine yönelmelerinin onları daha mutlu edeceği söylenebilir. Böylece Müslümanlar için hazzın yaşamın temel ereği olamayacağını bildiren İslami öğretiyle de uyum içinde olacaklardır.

Bu çalışma diğer psikolojik kuramları dışarıda bırakarak pozitif psikolojinin hedonist (öznel iyi oluş) ve eudaimonist (psikolojik iyi oluş) kavramsallaştırması çerçevesinde Müslüman bireyin olası turizm motivasyonlarını anlamaya çalışmıştır. Çalışmanın en önemli kısıtlılığı ikincil veri kaynaklarına dayalı teorik bir çerçeve çizmeye çalışmasıdır. Mutlaka Müslüman turistleri, turizm motivasyonları ve mutluluk düzeyleri açısından kıyaslama imkânı veren amprik araştırmalar yürütülmelidir. Bu çalışmalar, Müslümanların dini öğretileriyle çelişmeyen, çevreyle, doğayla, kültürlerle uyumlu, onlara zarar vermeyen, ruhsal büyümeyi gelişimi ve beraberinde de zevki getiren dengeli alternatif bir turizm anlayışının geliştirilmesine kaynak sağlamalıdır.

\section{Kaynakça}

Akarsu, Bedia. Mutluluk ahlakı. Ankara: İnkılap Yayınları, 1995.

Altunöz Sürücü, Özlem vd. “Evaluating Halal Tourism And Islamic Sensitives: Halal Hotels". Journal of Turkish Tourism Research 1/2 (2017), 64-77.

Arasteh, Mohammad - Eilami, Rahim Mohammadi. "The Role of Religion and Islam in The Tourism Industry of Iran". SSRN SSRN Electronic Journal, 2011. https:/ / ssrn.com/abstract=1773827 or http:/ / dx.doi.org/10.2139/ssrn.1773827. 
Aristoteles. Nikomakhos'a Etik. çev. Furkan Akderin. İstanbul: Say Yayınları, 2014.

Avrupa' da Sosyal Turizm (Barcelona Bildirgesi). Erişim 14 Nisan 2020. http:/ / www.festtravel.com/avrupada-sosyal-turizm-barcelona-bildirgesi, E

Aykut, A. Said.“İbn Battûta”. Türkiye Diyanet Vakfi Ansiklopedisi. 19/361-368. İstanbul: TDV Yayınları, 1999.

Azamat, Nihat. "Nâsır-1 Hüsrev". Türkiye Diyanet Vakfi Ansiklopedisi. 32/395-397. İstanbul: TDV Yayınları, 2009.

Bilim, Yasin - Özer, Özgür. Halal Tourism: The Case of Turkey. ed. Razaq. Raj - Kevin Griffin Conflicts, Religion and Culture in Tourism. 130-143, UK: CABI, 2017.

Brickman, Philip - Campbell, Donald. T. "Hedonic Relativism and Planning the Good Society. Ed. Mortimer Herber Appley". Adaptation Level Theory: A Symposium. 287304. New York: Academic Press, 1971.

COMCEC. Standing Comittee for Economic and Commercial Cooperation of the Organization of Islamic Cooperation. "Muslim Friendly Tourism: Understanding the Demand and Supply Sides In the OIC Member Countries". Erişim 13 Nisan 2020. http:/ / www.comcec.org/wp-content/uploads/2016/05/7-TUR-AN.pdf

Csikszentmihalyi, Mihaly - Coffey, John. “Why Do We Travel? A Positive Psychological Model for Travel Motivation". ed. Sebastian. Filep vd. Positive Tourism. 122-132. New York: Routledge, 2017.

Çağrıcı, Mustafa. "Seyahat". Türkiye Diyanet Vakfi Ansiklopedisi. 37/7-9. İstanbul: TDV Yayınları, 2009.

de Bloom, Jesscia vd. "Holiday Travel, Staycations, and Subjective Well-Being". Journal of Sustainable Tourism 25/4(2017), 573- 588. https:/ / doi.org/10.1080/09669582.2016.1229323

de Bloom, Jesssica vd. "Effects of Vacation from Work on Health and Well-Being: Lots of Fun, Quickly Gone". Work and Stress 24/2 (2010), 196-216. https://doi.org/10.1080/02678373.2010.493385

Dinçer-İstanbullu, Füsun - Bayram-Erkol, Gül. “İslami Bakış Açısıyla Helâl Turizm”. Uluslararası Türk Dünyası Turizm Araştırmalan Dergisi 2/1(2017), 26-42.

Filep, Sebastian - Laing, Jennifer. "Trends and Directions in Tourism and Positive Psychology". Journal of Travel Research 21(2018), 343-354. https://doi.org/10.1177/0047287518759227

Filep, Sebastian - Pearce, Philip. Tourist Experience And Fulfilment: Insights From Positive Psychology. New York: Routledge, 2014a.

Filep, Sebastian. Tourists' Happiness Through The Lens of Positive Psychology. James Cook University. Doktora Tezi, 2009. http:/ / eprints.jcu.edu.au/10842.

Filep, Sebastian. "Moving Beyond Subjective Well-Being: A Tourism Critique". Journal of Hospitality \& Tourism Research, 38/2 (2014b), 266-274.

https://doi.org/10.1177/1096348012436609

Journal of Analytic Divinity, https://dergipark.org.tr/tr/pub/jad Volume $4 / 2$ 
Filep, Sebastian. “Tourism and Positive Psychology Critique: Too Emotional?". Annals of Tourism Research 59(2016), 113-115. https:/ / doi.org/10.1016/j.annals.2016.04.004

Garcês, Soraia vd. "Positive Psychology and Tourism: A Systematic Literature Review". Tourism \& Management Studies, 14/3(2018), 41-51. https:// doi.org/10.18089/tms.2018.14304

Gilbert, David - Abdullah, Junaida. "Holidaytaking and The Sense of Well-Being". Annals of Tourism Research, 31/1(2004),103-121. https://doi.org/10.1016/j.annals.2003.06.001

Gnoth, Juergen. "Tourism Motivation and Expectation Formation". Annals of Tourism Research 24(1997), 283-304. http:/ / dx.doi.org/10.1016/S0160-7383(97)80002-3

Güçlü, A. Bâki vd. Felsefe Sözlüğ̈ü. Ankara: Bilim ve Sanat Yayınları, 2002.

Güzel, Berrin - Güzel, Özlem. “Evaluating The Resort Hotel Attributes Via Online Guest Reviews", International Academic Conference on Social Sciences and Humanities in Prague, 30-31 December 2016, Erişim 17 Nisan 2020. https://www.researchgate.net/publication/312914821_Evaluating_the_Resort_H otel_Attributes_via_Online_Guest_Reviews

Güzel, Berrin - Güzel Özlem. “Müşteri İslamî Otellerden Ne Bekler?” 1. International Halal Tourism Congress / 07-09 April 2017 Alanya / Turkey. ed. Kutay Oktay Hüseyin Pamukçu, 244-258, 2017. Erişim 17 Şubat 2020, https://www.halaltourismcongress.com/1IHTC/wpcontent/uploads/2017/12/1.-IHTC-Bildiri-Kitab\%C4\%B1.pdf.

Harrison, Julia. Being A Tourist: Finding Meaning in Pleasure Travel. Vancouver: UBC Press. 2003.

İlgürel, Mücteba. “Evliya Çelebi”. Türkiye Diyanet Vakfi Ansiklopedisi. 11/529-533. İstanbul: TDV Yayınları. 1999.

Jafari, Jafar - Scott, Noel. "Muslim World and its Tourisms". Annals of Tourism Research, 44/0 (2014), 1-19. https:/ / doi.org/10.1016/j.annals.2013.08.011

Karaarslan, Nasuhi Ünal.“İbn Cübeyr”. Türkiye Diyanet Vakfı Ansiklopedisi. 19/400-402. İstanbul: TDV Yayınları, 1999.

Kozak, Nazmi vd. Genel turizm: İlkeler-kavramlar. Ankara: Detay Yayıncılık, 7. Baskı, 2008.

Kur'ân-1 Kerîm Meâli. çev. H. Altuntaş \& Muzaffer Şahin. Ankara: Diyanet İşleri Başkanlığı Yayınları, 12. Baskı, 2011.

MasterCard \& CrescentRating. MasterCard-crescentRating global Muslim travel index 2015. Erişim 21 Mayıs 2020, https://newsroom.mastercard.com/mea/files/2015/03/GMTI_report_FINAL1.p df 
MasterCard-CrescentRating. MasterCard-crescentRating global Muslim travel index 2017. Erişim 21 Mayıs 2020, https:/ / newsroom.mastercard.com/asiapacific/files/2017/05/Report-Mastercard-CrescentRating-GMTI-2017-20mb.pdf

McCabe, Scott - Johnson, Sarah. "The Happiness Factor in Tourism: Subjectıve WellBeing And Social Tourism". Annals of Tourism Research 41(2013), 42-65. http:/ / dx.doi.org/10.1016/j.annals.2012.12.001

Milman Ady. "The Impact of Tourism and Travel Experience On Senior Travelers' Psychological Well-Being". Journal of Travel Research 37/2 (1998), 166-170. https:// doi.org/10.1177/004728759803700208

Hassani, Ali - Moghavvemi, Sedigheh. "Muslims' Travel Motivations and Travel Preferences: The Impact of Motivational Factors on Islamic Service, Hedonic and Product Preferences". Journal of Islamic Marketing 11/2 (2019), 344-367. https:// doi.org/10.1108/JIMA-11-2018-0215

Muslim Millennial Travel Report 2017. Erişim 18 Mayıs 2020. https:/ / www.halaltrip.com/halal-travel/muslim-millennial-travel-report/ /

Nawijn, Jeroen - Veenhoven, Ruut. "The Effect of Leisure Activities on Life Satisfaction: The Importance of Holiday Trips". ed. Ingrid Brdar. The Human Pursuit of WellBeing: A Cultural Approach. 39-53, Dordrecht: Springer, 2011.

Nawijn, Jeroen. “The Holiday Happiness Curve: A Preliminary Investigation into Mood During A Holiday Abroad". International Journal of Tourism Research 12/3 (2010), 281-290. https://doi.org/10.1002/jtr.756

Nawijn, Jeroen. "Determinants of Daily Happiness on Vacation". Journal of Travel Research 50/5(2011a), 559-566. https:// doi.org/10.1177/0047287510379164

Nawijn, Jeroen. "Happiness Through Vacationing: Just a Temporary Boost or LongTerm Benefits?". Journal of Happiness Studies 12/4(2011b), 651-665. 65 https://doi.org/10.1007/s10902-010-9221-y

Nawijn, Jeroen - Filep, Sebastian. "Two Directions for Future Tourism Well-Being Research". Annals of Tourism Research 61(2016), 221-223. https://doi.org/10.1016/j.annals.2016.07.007

Nawijn, Jeroen vd. "Vacationers Happier, But Most Not Happier After A Holiday". Applied Research in Quality of Life 5(2010), 35-47. https:/ / doi.org/10.1007/s11482009-9091-9

Nawijn, Jeroen vd. "How Do We Feel on Vacation? A Closer Look at How Emotions Change over the Course of a Trip". Journal of Travel Research 52(2013) 265-274. https://doi.org/10.1177/0047287512465961.

Pearce, Philip. L. “The Relationship Between Positive Psychology and Tourist Behavior Studies". Tourism Analysis 14/1(2009), 37-48. https://doi.org/10.3727/108354209788970153

Pearce, Philip L. “The relationship between Positive Psychology and Tourist Behaviour Studies". The International Academy for the Study of Tourism Conference, Mugla, Turkey. 2007. 
Ryan, Richard M - Deci, Edward L. "On Hapiness and Human Potentials: A Review of Research On Hedonic and Eudaimonic Well-being". Annual Review Psychology, 52 (2001), 141-166. https:// doi.org/10.1146/annurev.psych.52.1.141 ·

Ryff, Carol D. "Happiness is Everything, or is It? Explorations on The Meaning of Psychological Well-Being". Journal of Personality and Social Psychology 57 (1989), 1069-1081. https:// doi.org/10.1037/0022-3514.57.6.1069

Ryff, Carol D. "Psychological Well-Being Revisited: Advances in The Science and Practice of Eudaimonia". Psychotherapy and Psychosomatics 83 (2014), 10-28. https:/ / doi.org/10.1159/000353263

Sarı-Çallı, Didem. "Uluslararası Seyahatlerin Tarihi Gelişimi ve Son Seyahat Trendleri Doğrultusunda Türkiye'nin Konumu". Turizm ve Araştırma Dergisi 4/1 (2015), 4-28.

Seligman, Martin E. P. "Flourish: A Visionary New Understanding of Happiness and Well-Being". New York: Free Press, 2011.

Sirgy, M. Joseph - Uysal, Muzaffer. “Developing a Eudaimonia Research Agenda in Travel and Tourism". ed. Joar Vitterso. Handbook of Eudaimonic Well-Being. 485495, New York: Springer, 2016.

Sirgy, M. Joseph. "Toward a Quality-of-Life Theory of Leisure Travel Satisfaction". Journal of Travel Research 49/2 (2010) 246-260. https://doi.org/10.1177/0047287509337416

Sirgy, M. Joseph. Leisure Well-Being. The Psychology of Quality of Life. Dordrecht: Springer, 2012.

Smith, Melanie Kay - Diekmann, Anya. "Tourism and Wellbeing". Annals of Tourism Research 66 (2017), 1-13. http:/ / dx.doi.org/10.1016/j.annals.2017.05.006.

Süt, Abdurruahman. "İslam ve Turizm Ilişkisi". Turkish Studies - International Periodical For The Languages, Literature and History of Turkish or Turkic 9/11 (2014), 479-497.

Timothy, Dallen - Iverson, T. “Tourism and Islam: Considerations of Culture and Duty". ed. Dallen J. Timothy - Daniel H. Olsen. Tourism, Religion and Spiritual Journeys. 186-205, London, New York: Routledge, 2006.

Tontuş, Ömer. Tüm Yönleriyle Sağlık Turizmi. Ankara: T.C. Sağlık Bakanlığı, 2015.

UNWTO, The World Tourism Organization. Glossary of Tourism Terms. Erişim 22 Mayıs, 2020. https:/ / www.unwto.org/glossary-tourism-terms.

Uysal, Muzaffer vd. "Progress in Tourism Management: Quality of Life (QOL) And Well-Being Research in Tourism". Tourism Management 53(2016) 244-261. https://doi.org/10.1016/j.tourman.2015.07.013

Voigt, Cornelia. “Employing Hedonia and Eudaimonia to Explore Differences Between Three Groups of Wellness Tourists on The Experiential, The Motivational and The Global Level". ed.Sebastion Filep vd. Positive Tourism. 105-21, Lonon, New York: Routledge. 2017. 
Gülmez, Çiğdem. Müslümanların Seyahat Motivasyonları: Pozitif Psikoloji

Perspektifinden Bir Değerlendirme

Voigt, Cornelia vd. "Hedonic and Eudaimonic Experiences among Wellness Tourists:

An Exploratory Enquiry". Annals of Leisure Research 13/3 (2010), 541-562.

https:/ / doi.org/10.1080/11745398.2010.9686862

Yazır, Elmalı Hamdi. Hak Din̂̂ Kur'an Dili. Sad. İ. Karaçam vd. (2. Cilt). İstanbul: Azim Dağıtım, 2000.

Yeoman, Ian. Tomorrows Tourists: Scenarios E Trends. Oxford: Elsevier, 2008.

Zamani-Farahani, Hamira - Henderson, Joan. "Islamic Tourism and Managing Tourism Development in Islamic Societies: The Cases of Iran and Saudi Arabia". International Journal of Tourism Research 12 (2009), 79- 89.

https://doi.org/10.1002/jtr.741. 